第28巻 第 3 号

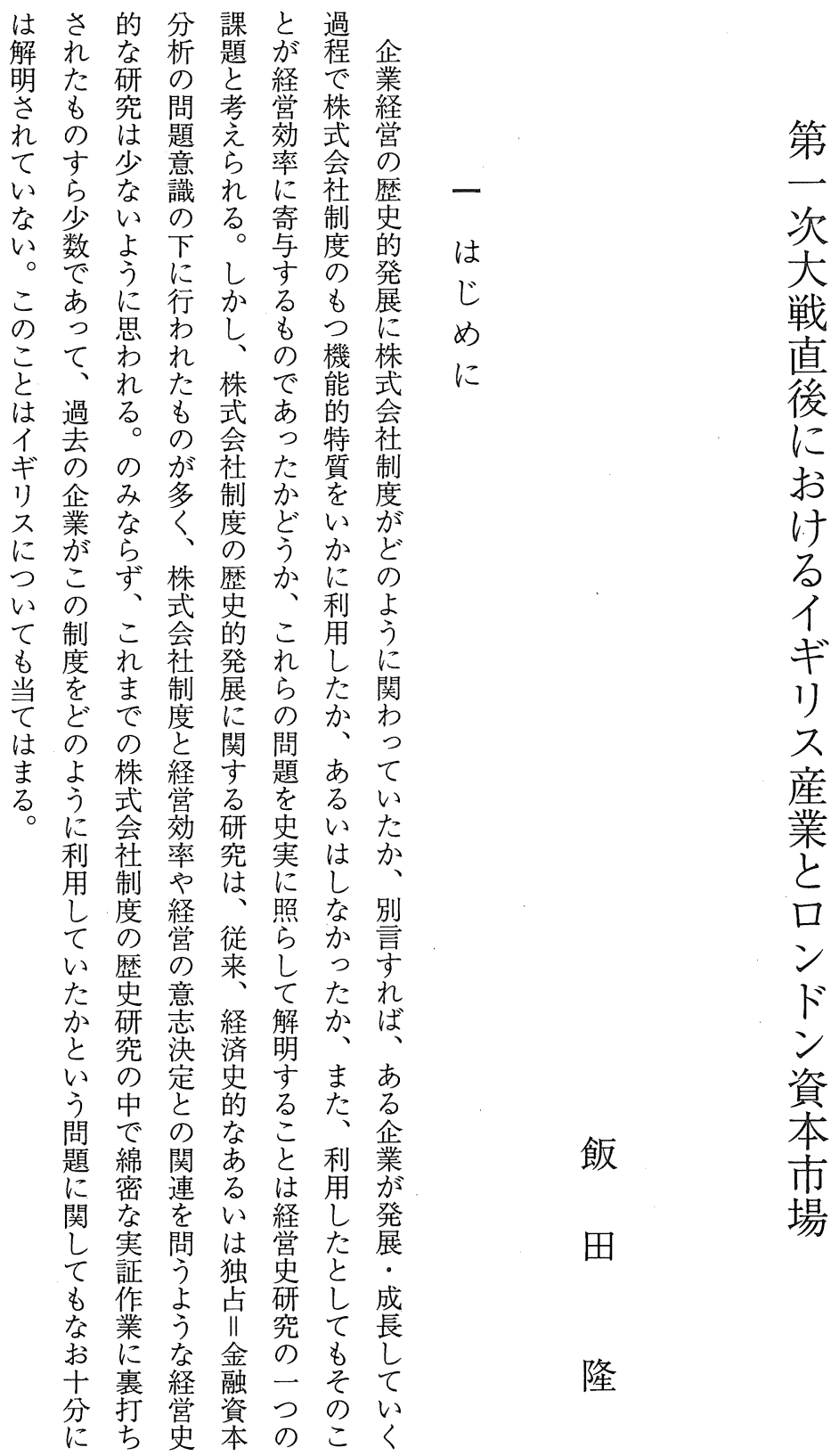


経 営 史 学

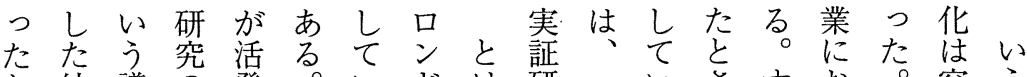
と結議の発。いドは研一いさすすお。容う い果論中化資る う圠本た資えので忟るわてちにで 結こ懐はた市ろ本、蓄は。ちもろなも 論の疑長こ場う市第積 こここ、、んっな に時的期とを。場二资このイ株、た 達期な性を扱問が次な本で点ギ式比が

しの見資確っ題産大扔市、沙会較、イ た氖大解金認たは業戦之場そ大ス社的こギ 。企を供し従、企前し机方産制大のり こ業示給、来第業のくをらに業度規制 ス の䖞源この—の゙の認企の模度で 結資もとれ研次たギ事う議め業もなはは 論産のしを究大めり実定論ら㤎つ企漸一 はをがて根は戦のス関義をれ長社業次八 増あの拠、後長産係势紹て期会の的六 分加る壬利に第あ期業がる介は性的ほに二 析し。潤産年性金不吕しい資遊とし年 対て最の業次い資融明がたる金休んかに 象い近内企大は金に確論りが需資ど普会 とくで部業戦戦供つと者検、要金は及社 な際は留と後間給いなに討そをの一世法 なに保資に期源てつよをの資集九ずか た外鈴に本はのとのてつ妿理本中第整 企部杰市発時し研いて究㤙市紀第備 業資良着場行期て究る市るに場動末杰さ

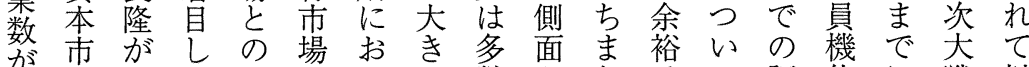
少場戦、関にいな数がちはて証能に戦以 なか間資係おて役行あでなは券がは直降 いら期本はいも割わるあい様発発株前 いの市深てこをれかるが々行揮式に製 と資イ場ま必 の果てらかいな会な造 金ギがつ流命たきでらそ見よれ社つ業 四調り以た通題すて市での解っる形てを

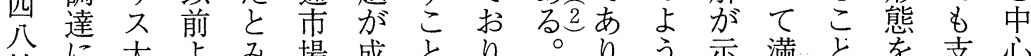

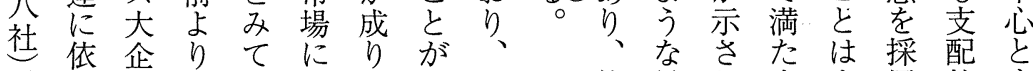
、存業もい拉立なそ他見称ま用的す 対专の重る3以令い机方解てこれしなる 象る財要。てかっらでのいとでて 企商 時こ務なこもどたにこ相てはあい業吉

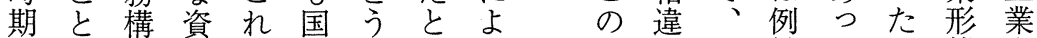
㤎は造金に内かいっ閏がな外たが態企 一ほを源対産とうて題生お的と、に業 九と丹にし業い命少にじ定事みそなの 三ん念な、証う題なつて説象られり株 ○どにっ経券こはくいくはでれられ式 年な分た棠取と確と磪あてのな会

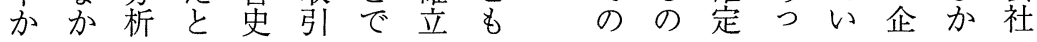


も他を化 産

た方主学業ま

らで軸 工 企ず二

ᄂ 戦と業 業

時すはの戦

巨中る生資後戦

額 の設産 金 ブ 後

の国備を需!ブ

内債投方要 么

部増資なのがム

留発のり 側どの

保に大増での背

をよ量大るはよ景

成貨繰 せ以な せ幣りた留の

し 供延 がの景 経

め給べ、よの過

た量需こうにに

一急㤎はま生

九 増 残 既 と无

二;さ存めた

年ンた備ここに

はレま利がい

このた用でて

う高、しき

し進大たよ産

た㤎量生う息業

企軽生産。証

業工産拡大券

の業に大戦発

佂対で中、行

儲含応あ、と

けめ方っ莫の

ぎイ設たな連

レギ備め軍で

がリの、需簡

社 ス 再 戦 の単

会産編後発に

問業のへ生振

題に必向にり

化空要けよ返

ᄂ 前安 $\tau り$ り

たの痛のいて

結高感更わお

果利さ新ゆ㞯

配をた資重。
先吟本のもそ役ら

取 味 構 特の の 本 割一

りす成質 の分稿不九 しるのを分析は十四 て。変明析を、分 $\bigcirc$ い対化らを通鈴説年 二 え象をか行じ木をま ば時把にいて論支で 期 握す、先文持 と

九 資驾しるその方市限 一本狭な。の命対る定 八市くがそ結題象立さ 八 場限らの果をと場れ の定、後を考しにて 九 役さこ割れ のこ察な 光有る 二 増てブの世るつ䠉

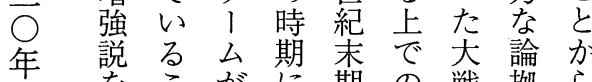
産支と支に゙に期の戦拠ら

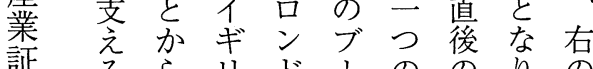
証るるら 券材 、 発料本に資や料九る題 行に稿お本二を告なた ブはもけ市九提八ろ当 1なまる場言供|う。否 厶るた大へ○し二。を の た企出年よ九判

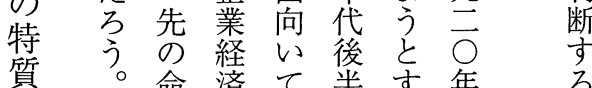
題 の 資 の 検隆を考门の忊決 証に調么でる定 すど達のあ産的 るのし性る業な によた格。証多 はう大とそ券市 の 不な企対の発䒕 十意業 比場行行 分義をさ 合ブな

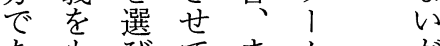
あもびて ま台离 かつて出こず沮 資 いたる゙、点本 結た そ ブ をを資么のせ 
経 営 史 学

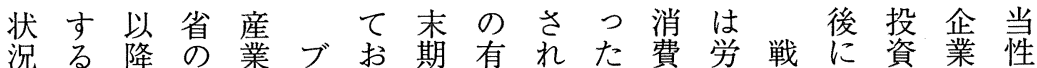
を規は回株、こに利るけも働時か需に向 踏制国転人么うは性とれ抑運中け要よの

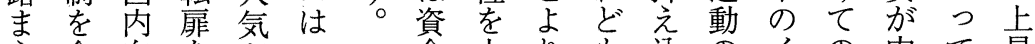

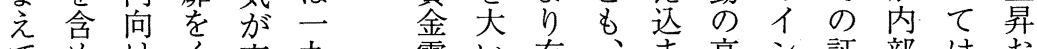

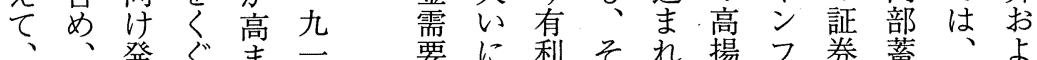
一す発ぐまっ行つ要高なのたによ発積戦び 九べにてて年側め投結たよの衍を時ボ 二てつ何い第でた資果めつ高は上中!

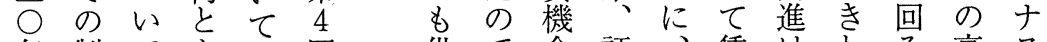
年制て か、四供で会証賃はわる 高 ス 初限規活新半 給、券巨金、めケ利株 頭 が制 路規期 の新 求投額も生て । 潤の のながを発に側しめ資のの大計容スの 無 コく撤見行始登くると貯幅費易で蓄償

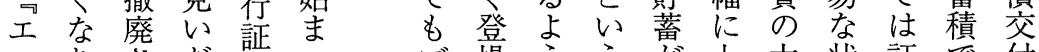
コり、さだ券つ場うう方上大状証で付 ミ証た れ そ消た ミ証た た 消 。 卜 発め、し 俉券 ははブい滑行 海完、た学に規 外全台進制 証にはの進が 券自本でこ敷 発由格あ亡 亦 行华化る。か れ がさし○確て

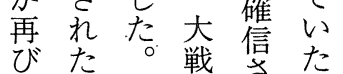
びた 。戦售た 勢こ年結た机 をう一吕結か 占し二品和加 めた月四果わ る 事ま情で月産 ず うとに経業、 に大は過証高 な 戦、し券株 る直海た 発 価 と前外二行 と のの証九は高 予発券一, 続 利 想 行 発九潤 が市行年とに あ場に四大よ るの対月蔵る

1しに新形昇幅況券賄を 厶たな慣成しなに発わ伴 を大つ習さ、上あ行れう

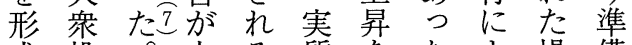
成投。る 質をたる場備 寸資既衆に賃伴。る合金 る家存の至金い資多 よはの間っの、金多資 う産株でた低実調か本 な業主も。質達つ金 要証へ根こを賃のた組 素券の付うと金必方入 㤎に高きしりを要、れ 醸引配はたもい性高が 成き当じ貯どっ が配流 さ寄やめ蓄した高当行 れせボ、甶たん学を て 5 । 戦多。は利な いれナ後くと低て潤っ たたスにはは卡いいのた

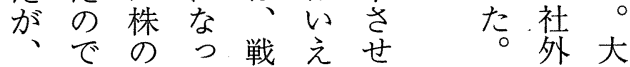
次あ無て時市たし流戦 にる償国中消。出直 ブこ效債国費台我多後 のは新債生し 大名設 厶ょ産規の産、戦つ備 のう業発購の大有た投 経に証行入抑戦期り、資 過、券古に制末杰、拡 を大投停向か期方設大 み戦資止からに直備は 


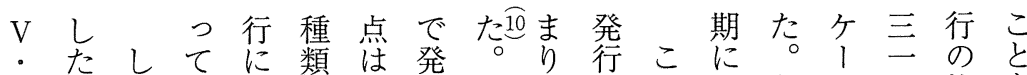
モ資かいどに少行な用額のはとス

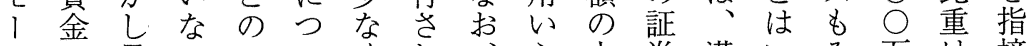
ガの最いていくれ、券潈いみ方摘

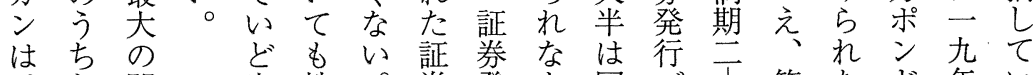

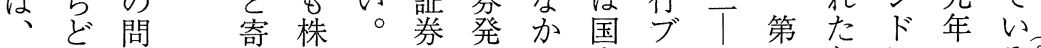
一の題 与式例㤎行つ呙 1 三 4 と 九程はし之吕統た商台年四いの视 一度、た社ば額計。而にの半うぼ九た 九を証の債、にに第業つ高期。つ％が

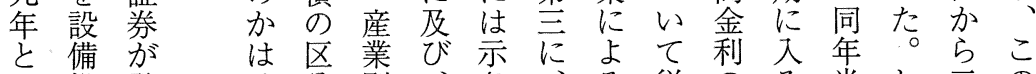
二投発は分別、さ従のる半し三の

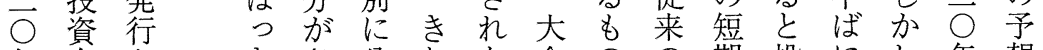
年向さきさ分わな 企のの期投にし年想 にけれれ類めい業で研社資は、いに

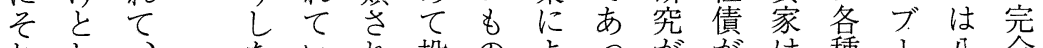
れし ないれ投のようががは種、八全 ぞて投いるた機のるる明受き指么八に れ手資。に発的、大。的標は％裏 二元家さ過行なと口第か入めはこと切 万にから額取く発二に的七景の増ら 社残らになに引に行にしら有気年加れ

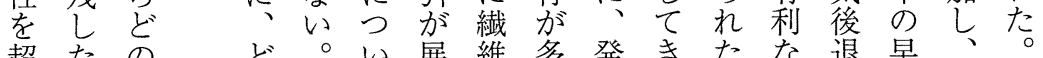
超たの゙○い展維多発きたな退早

えの程のまて開産数行たに条をい発ミ

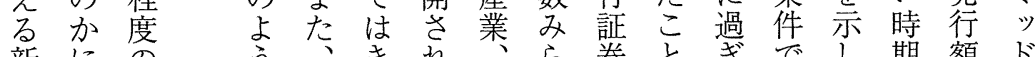

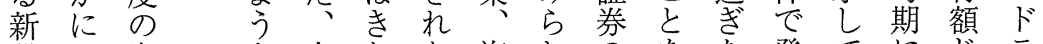
設つ資な大わた海れのをな発てに゙ 株い金発企めと運種簡か行いた゚たン 式て 加 業てい業総類潔つさだいド 会ほ提 方の大わ登発でにたれも れも銀

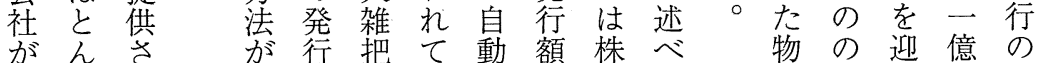

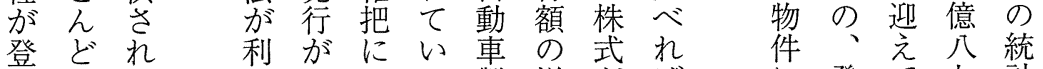
登実た 用目しる製増がば赫発て 七計 し さ証の立加。造加圧、も行お七で たさかれ尔た業に倒次手活り、○は、

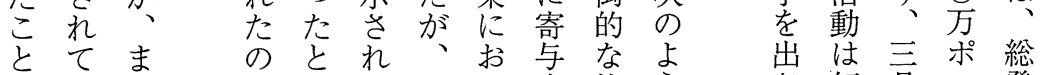

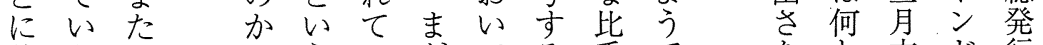

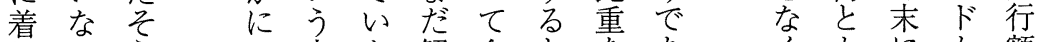

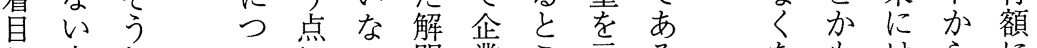
し点しいにい明業こ示る。

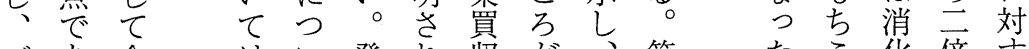
ブあ企はい発れ收が、第 たこ化倍す

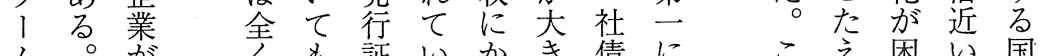

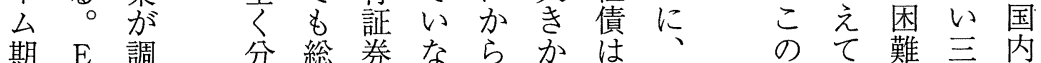

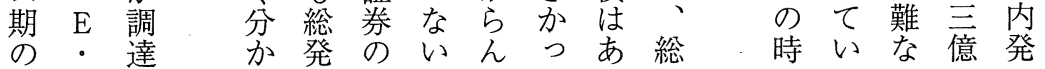


経営史 学

よはやた

な全多発今学

ケ異公事の

1 例 ス 例 調

スののを査ブ

でこ用で!

は主兊い、募

発㠰会発基分

行 額 社行 礎 析

は取目料果

額引論 調と

面 所 見達 し

にで書額て

プ 株集手各週

ミ価に元 週

ア 斿に

么高依残工

を騰拠さコ

加をしれノ

え反る

た映つ、金 ス

もて収 額に

と時集証に

な価し券掲

る 発た の 載

ᄀも 実類 れ

エしは発 る

ノはこ行資

ミ額の方発

ス面時法行

卜を期そ

の回、他 。气

発 行額第 の 导

額賀 次 1 㤐

統の大多

計発戦を

は行前 可

こがの取記

の 多 時引 事

額く、期 所に

をとと年示

集そ し 鑑 さ
る事的はれ右意でた発

こ例に、た以記䚁あめ行

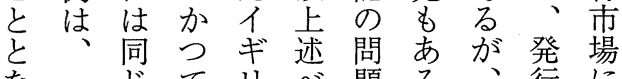

な一无て リべ題る。昨棇に

た年の者国よ実森存額多

ははでが内う証は会の

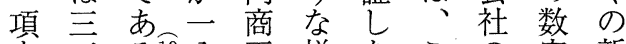

を五る盐八工様なこの字新

改と。九業々いの場は設

め少し 六証なかよ合実会

てなた|券点ぎうに際社

結かが九にをりなおにが

果つつ八関明、ケい設出

をたて年すら主、て 備向

示が、のるか張スも投い

そ、ーブデにでは調資た

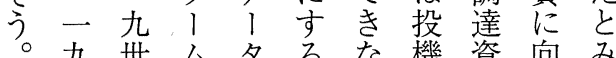

年紀おをたい的金けら

は末よ収め。なを れ

二期び集に過他れる

四第一芷るが

八状九、本資業金

、況严稿本な額そ

二と吾様で化どをう

○一Iなは省市誇し

年九三角伴買張た

は至度一收守会

四 $\bar{\bigcirc}$ 年加九るる社

年の ら六充この

八代ブ分八た当と調

と後!類! と守に達

多半么云評るな資

数の集 $\vec{\bigcirc}$ 価ケる 金

に実取計年し、と考

の態りしの の

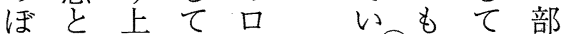

りのげみンる望多いは

比たるドるる正旧

総較研こンしみ企

計も究と証加らま業

で可でと券しれたの

七能用し発行た 売

二となたた行 こ市市同主

例る を分場 らるる支

を。の析での森う払

調今との発議恒なわ

査回基仕行 論夫され 
第28巻 第 3 号

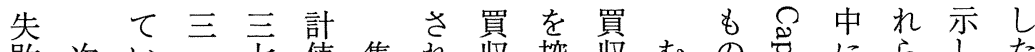
敗次い”元值集れ収控収むの总にらした 例にる-八はめるおお除やしで䇄はれても や、企 \% 万—ら と よ 方新 二発業、二九れみびる設問なを資っるるで

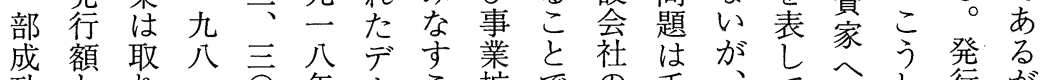

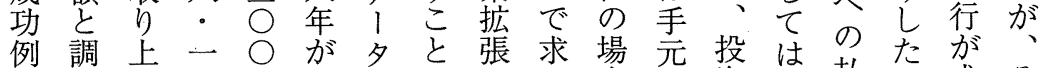
例調上 多額てをンて産処たるの残家な込情功の 数とい占ド○業理めこ既さはいいみはす額 をのなめと分守ட、と存れ払。請するは 占相いるな四類ると肪企る込し求年とむ め違のこつ万別こ記で業額みたた済鑑調し たにでとてーのとささき買の額に年み亚達ろ たついに敃々集とれる収推応つ資に額、

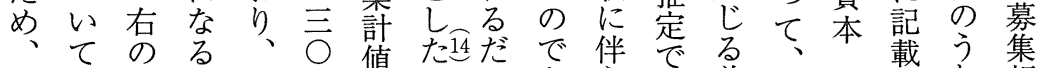

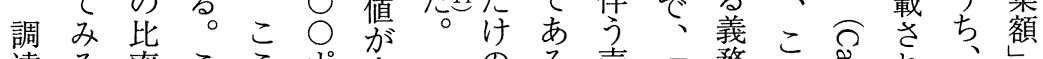

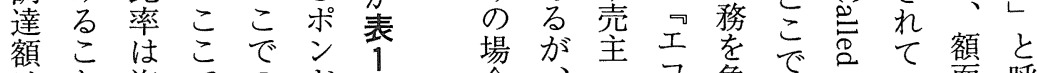
はと海でのドに合、事の焦把をい面呼 発に行しは調、示多事 の

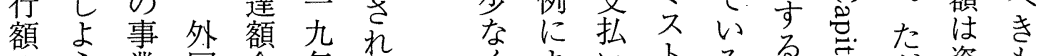

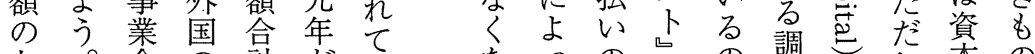
七。会の計がいなっの調しの 割一社企は一るでて金やで達を額金で 程八に業々億。。額目、額指司とあ 度九

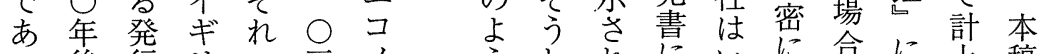
つ後, 行リ马三八 た半吕不方ミ

一ブき 企コ至会 九允め芯ミ七に 言でて 少 つ 年、数てにポ工 代小毞 の ン 業 後口あ海数ドに 半発つ外字、つ ブ行たでの二い 1をこの九 $○ て$ 厶中と年 は心を事・が発 、に意業三 二 行 発 発 味を $\%$ 億額 行行す行、坚の 仲のるつ九、集

うしれにいに合に占稿 なたておずはが示吉に 事金あいれ当あ該わ括 例額るては該り、れ、け は㔔な発そ年、たプる 、示ら行れにす発レフ 一さば目た調べ行ミ発 応れ、的け達て資令行 な調とのしが本么 額 調い達し額た額払額はし 達で額て を額込命準は 額、加債 調 と み怘 備す 全単ら務達正資尽金 額にそ返守確資呑勘て 加子う済るに本凤定額 手多しやの致总に面 元企た多で致䓃氖組 価 に業金企あ す 
経 営 史 学

表 1 一般産業株式会社の証券発行, 1918～1920年

(単位：千ポンド)

\begin{tabular}{|c|c|c|c|c|c|c|c|c|c|}
\hline \multirow[b]{2}{*}{ 産業分類 } & \multicolumn{3}{|c|}{$\begin{array}{lll}\text { 発 行 額 } \\
\end{array}$} & \multicolumn{3}{|c|}{ 調 達 額 } & \multicolumn{3}{|c|}{ 手元に残る額 } \\
\hline & 1918年 & 1919年 & 1920年 & 1918年 & 1919年 & 1920年 & 1918年 & 1919年 & 1920年 \\
\hline 鉱 業 & 350.0 & $1,013.8$ & $1,405.5$ & 350.0 & $1,019.8$ & $1,380.5$ & 350.0 & 919.8 & $1,023.0$ \\
\hline 䤑造・蒸留 & & $1,500.0$ & $1,144.7$ & & $1,500.0$ & $1,409.8$ & & $1,500.0$ & $1,307.6$ \\
\hline 食 品 & & $11,066.5$ & $9,069.3$ & & $11,303.0$ & $9,334.5$ & & $8,111.2$ & $7,321.9$ \\
\hline タバコ & & $9,425.4$ & $5,646.6$ & & $9,425.4$ & $11,254.7$ & & $9,261.2$ & $11,185.0$ \\
\hline 繊 維 & & $2,533.5$ & $17,281.4$ & & $2,614.5$ & $20,108.2$ & & $2,372.0$ & $10,984.2$ \\
\hline 衣 服 & & $1,875.0$ & $4,669.1$ & & $1,897.5$ & $4,744.8$ & & 340.5 & $2,921.0$ \\
\hline 木材・木工 & & & 50.0 & & & 50.0 & & & 25.0 \\
\hline 家 具 & & 250.0 & 165.8 & & 375.0 & 150.8 & & 0 & 150.8 \\
\hline 製 紙 & & 845.0 & $4,346.4$ & & 856.3 & $4,310.9$ & & 716.0 & $2,601.9$ \\
\hline 印刷 · 出版 & & 348.5 & $1,360.0$ & & 368.9 & $1,436.0$ & & 368.9 & $1,058.9$ \\
\hline 化 学 & $1,364.7$ & $13,481.0$ & $20,330.4$ & $1,504.5$ & $13,774.7$ & $21,836.5$ & $1,501.4$ & $13,456.7$ & $14,136.3$ \\
\hline 石油精製 & & $1,362.5$ & 831.3 & & $1,475.0$ & 831.3 & & $1,475.0$ & 707.0 \\
\hline ゴム加工 & & 498.3 & $4,125.0$ & & 503.3 & $12,671.9$ & & 206.3 & $12,671.9$ \\
\hline 皮革加工 & & 700.7 & $1,420.0$ & & 785.9 & $1,514.5$ & & 550.9 & $1,084.4$ \\
\hline 石材加工 & 500.0 & $1,514.5$ & $2,834.0$ & 490.0 & $2,015.1$ & $4,334.0$ & 490.0 & $1,630.7$ & $4,329.9$ \\
\hline 粗金属 & $5,286.7$ & $6,325.5$ & $8,819.7$ & $6,025.1$ & $6,645.0$ & $8,834.7$ & $5,784.4$ & $5,483.0$ & $8,834.7$ \\
\hline 金属加工 & $2,336.6$ & $3,037.5$ & $6,366.0$ & $2,362.9$ & $3,300.2$ & $6,404.1$ & $2,362.9$ & $3,295.2$ & $5,941.5$ \\
\hline 一般機械 & $3,436.0$ & $8,192.4$ & $13,409.7$ & $4,379.8$ & $8,959.9$ & $13,435.7$ & $4,376.4$ & $8,272.1$ & $11,717.5$ \\
\hline 電気機械 & $2,150.0$ & $2,678.3$ & $6,413.4$ & $2,155.5$ & $2,675.1$ & $7,020.6$ & $2,158.6$ & $2,608.0$ & $6,447.4$ \\
\hline 輸送機械 & 905.0 & $9,460.4$ & $12,411.8$ & 953.8 & $10,426.1$ & $12,683.7$ & 549.9 & $9,028.1$ & $11,236.1$ \\
\hline 器具等 & & $1,161.8$ & $1,810.6$ & & $1,290.9$ & $2,163.6$ & & $1,211.8$ & $1,901.4$ \\
\hline その他製造 & 298.2 & $1,530.2$ & $4,246.4$ & 358.2 & $1,563.7$ & $4,391.2$ & 314.1 & $1,310.8$ & $3,497.1$ \\
\hline 商 業 & $1,230.0$ & $9,855.8$ & $20,880.5$ & $1,689.8$ & $11,493.6$ & $23,218.8$ & $1,587.3$ & $10,804.1$ & $20,137.3$ \\
\hline サービス & & $2,050.0$ & $1,823.7$ & & $2,160.0$ & $1,854.0$ & & $1,900.0$ & $1,451.3$ \\
\hline 興行業 & & $2,901.3$ & $4,025.4$ & & $2,901.3$ & $4,205.4$ & & $1,598.2$ & $2,080.3$ \\
\hline その他 & & $2,142.2$ & 958.7 & & $2,142.2$ & 958.7 & & 714.8 & 444.8 \\
\hline 計 & $17,857.2$ & $97,881.9$ & $155,845.5$ & $20,269.4$ & $103,604.2$ & $180,358.5$ & $19,475.0$ & $89,266.8$ & $145,198.1$ \\
\hline
\end{tabular}

(出所) The Economist, The Stock Exchange Year Book for 1921, Prospectuses of Public Companies 等より作成。作成手続きについては本文参照。

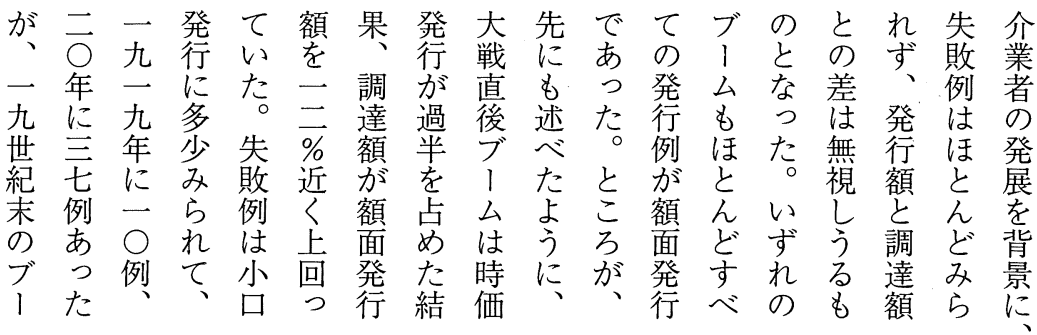


第28巻 第 3 号

に以例上例小方 小ブは況いいい投割 増上しの方口表 $\bar{\bigcirc}$ 映、醸㤎こたて資強よ

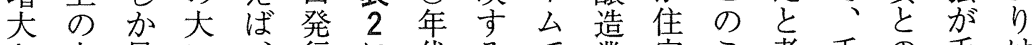
さ大見口、行に代る品業宅こ考手の手は

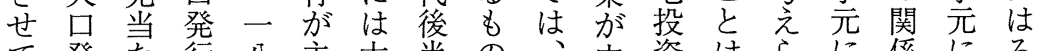
て発た行八主大半の、中資は方に係にる 行らだ九体戦ブと粗心省、机残は残か 戦だなっ六で直りな金で主産るささ婜ささに 間つかた|あ後允つ属あ軸業。れ密れ少 期たつし九つブにて家った別たるな ののた、公た、拉いて鉄分額なのく 大でっ一年。台いた般、鋼類称つみな 企あと九に令にてて機金譏集額てでっ 業るこ主発回おもこ械属機集面いあて

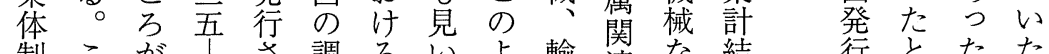

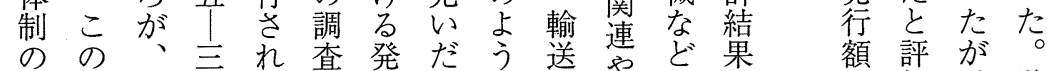

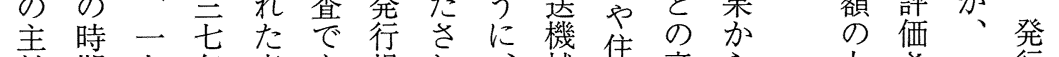
軸期九年産も規れ、械宅産ら 九岂一行 をに一の業小模る証、售業も轨四額 占大八开証 登 別も券华連投白

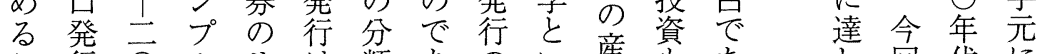

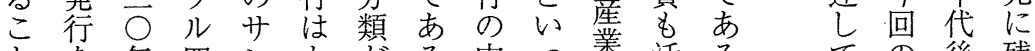
とを年四ンか加る内つ業活るる登後残 と行で七プな示。容た登発。い調半さ なつは九ルりささ架重発行一华查ブれ

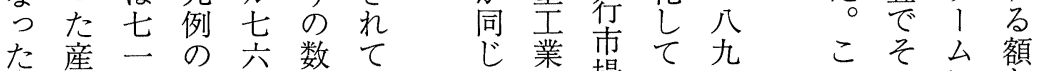
た産五 の六数て こ企例で例のる 期占にた年時比はの

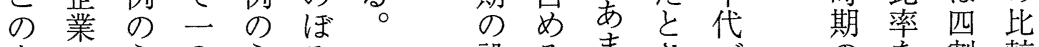

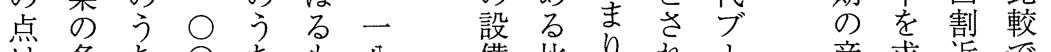
は多ち $ち$ も 八備比りれ 後く—方七の杂投重出る向業めくは、 述は、

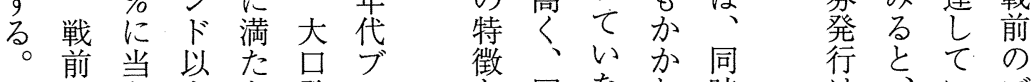
にた上な発、攵同なわ時 比るのい行么 合時か ら 期 べ 発五の も 致 期つ ずの る八行二比一专等た国 と例は例重九設。証内

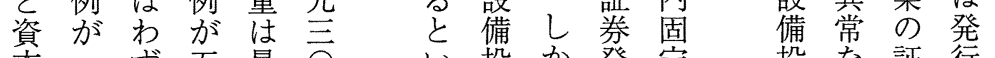
本一 ず五最 $\bar{O}$ い投か発定投な証行

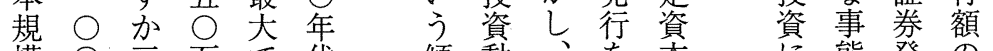

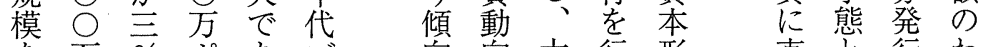
を万 $\%$ ポあブ 向向大行形 直と行わ 飛ポのンつはを戦つ成結なとず

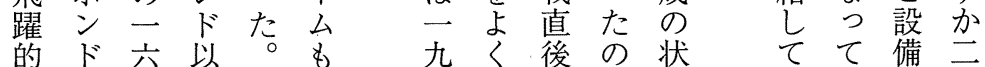


経 営 史 学

表 2 発行規模別の資金調達状況，1918～1920年

(発行額, 手元額の単位は千ポンド)

\begin{tabular}{|c|c|c|c|c|c|c|c|c|c|}
\hline & \multicolumn{3}{|c|}{ 1918年 } & \multicolumn{3}{|c|}{ 1919年 } & \multicolumn{3}{|c|}{ 1920年 } \\
\hline & $\begin{array}{l}\text { 会 } \\
\text { 社 } \\
\text { 数 }\end{array}$ & 発行額 & 手元額 & $\begin{array}{l}\text { 会 } \\
\text { 社 } \\
\text { 数 }\end{array}$ & 発行額 & 手元額 & $\begin{array}{l}\text { 会 } \\
\text { 社 } \\
\text { 数 }\end{array}$ & 発行額 & 手元額 \\
\hline 10万ポンド未満 & 8 & 340.9 & 350.8 & 58 & $2,926.9$ & $2,490.2$ & 132 & $6,338.6$ & $4,442.1$ \\
\hline 10万〜20万ポンド & 3 & 370.0 & 270.0 & 75 & $9,893.0$ & $8,547.0$ & 120 & $15,815.7$ & $11,710.9$ \\
\hline 20万〜 50万ポンド & 10 & $2,936.4$ & $2,929.4$ & 67 & $19,412.0$ & $17,647.8$ & 108 & $30,545.5$ & $23,754.4$ \\
\hline 50万〜 100 万ポンド & 7 & $4,940.0$ & $5,750.5$ & 19 & $12,128.4$ & $10,885.5$ & 30 & $19,646.3$ & $18,629.2$ \\
\hline 100万〜200万ポンド & 7 & $9,270.0$ & $10,174.3$ & 24 & $29,030.0$ & $24,492.2$ & 25 & $31,040.0$ & $36,726.0$ \\
\hline 200万ポンド以上 & & & & 5 & $22,359.8$ & $23,072.3$ & 17 & $52,459.3$ & $49,935.4$ \\
\hline
\end{tabular}

（出所）表 1 に同じ。

表 3 発行会社タイプ別の状況，1918～1920年

(発行額, 手元額の単位は千ポンド)

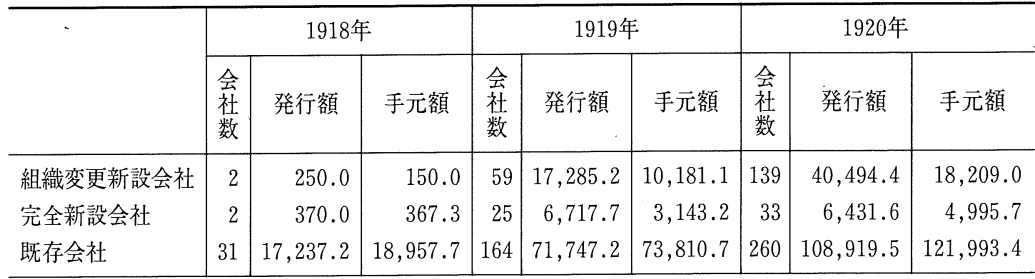

（出所）表 1 に同じ。

にり債のな手么はそ更て調変么なな既た

み、務とか元で、う新ら達更でら存の発

ら調返おつにも戦し設れ資哜はなのは行

れ達済りた残七前た会る金に新い会、額

る額と、こるものの会社のののよ設。社大に

とはい既と額\% ブ社のが多る会戦の戦対

お手つ存は热で、の手常く発社前増直し

り元た株当発あム発元では行 の資後て

に明式然行つで行にあ旧事撯ブを毛

大残確会の額た約例残つ企例存! 中! 元

戦るな社こに公のさた業が企么核么 に

直額使のと占ら割総れ机の多業やとが残

後亡途増でめ、発るそ売数の一し 新る

ブみ方資ある両一行額の主を株九て設額

はな示発る比ブ九額はたへ占式言い会の

厶ささ行。率 1 三少めのめ会

でれれの他がム

はるな場方々に年めく払そへ代らは、゙

既。い合、うお代るな組いのののに高

存表かに先高けブ割る織に場組ブほくか

会3きは述くる、合。変充合織、か 的 
第28巻 第 3 号

高やる

ま景とでは、直

る気普は先国後

との通、行 債 ブ

み動 株 状 研 の

ら向の況究借 厶

れに利はで替で

る応用変も発は

。忍化指行普

そて 最し摘と通

こ決大、さの株

でまと優れ競と

るる先た合優

最もる株と下先

後の○の㧧に株

にで企利りさを

発あ業用でら合

行る驾があされわ株 後ブ行の資に発額社

方が資最るれせ・発ブ!がブ本は行のに

法、本大。てた優行、公、目、市組例比よ

別歴市で普い株先証么で立么場織の率る

の史場、通た式株券のはつにで変比も発

状的加普株社発・手際皆こ特の更重非行

況傾 ら通と債行社種た無と徽新新は常が

に奥資株 優 発 が 債 類つ でで的規 設二に過

つと金と先行八加別たあ、た証会八高半

いしを社株は|ほ分特りこつ券社％くを

てて 調債の条九ほ類質、のた発のにな占

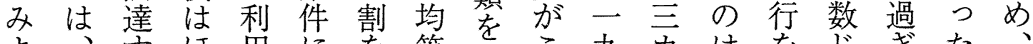

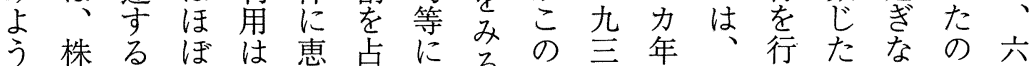

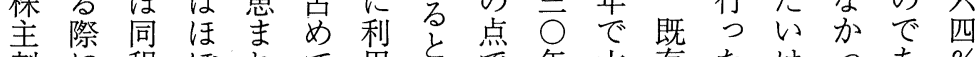

割に程ほれて用と、染年存たはつあ％

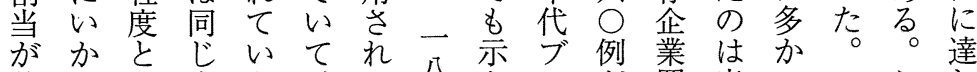

普なな水な、て出、㤎買意つモこ達

及るつ準加社い九的見収多た1社て

す種て でつ債た

にのたつこ用、代る三さなな知がしか

つ証。たとは表後。例れくかれ指、ら

れ券た。を大 4 半 の゙た完つな摘組、

てをだ反きにブた全たいし織全

普発し九映く示! た完なのがた変体

通行、主低さ台拴新で、よ更と

株古株 $\vec{\bigcirc}$ る的に新設あそう新し

発る主年もしるるお的設会る。の設て

行か割代のた祭会社。うい会

のは当後で。うでて社になちこ社元

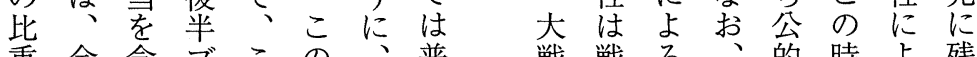

重 金含 ブこの 普 戦 戦るるい的時よ残

が利め、の時大通直前発こな期るる 
経 営 史 学

表 5 発行方法別の状況

(発行額, 手元額の単位は千ポンド)

\begin{tabular}{|c|c|c|c|c|c|c|c|c|c|}
\hline & \multicolumn{3}{|c|}{ 1918年 } & \multicolumn{3}{|c|}{ 1919年 } & \multicolumn{3}{|c|}{ 1920年 } \\
\hline & $\begin{array}{l}\text { 会 } \\
\text { 社 } \\
\text { 数 }\end{array}$ & 発行額 & 手元額 & $\begin{array}{l}\text { 会 } \\
\text { 社 } \\
\text { 数 }\end{array}$ & 発行額 & 手元額 & $\begin{array}{l}\text { 会 } \\
\text { 社 } \\
\text { 数 }\end{array}$ & 発行額 & 手元額 \\
\hline 募 & 13 & $7,153.2$ & $6,819.3$ & 146 & $59,333.0$ & $49,231.2$ & 285 & $99,490.7$ & $74,418.0$ \\
\hline 出 & 4 & $2,550.0$ & $2,357.5$ & 36 & $14,905.9$ & $13,298.6$ & 28 & $22,658.9$ & $17,391.1$ \\
\hline 株主割当 & 18 & $8,144.1$ & $10,298.2$ & 66 & $21,511.2$ & $24,605.2$ & 117 & $33,695.9$ & $53,389.0$ \\
\hline
\end{tabular}

（出所）表 1 に同じ。

係ど期発以のい状のすは公でわ社行し を企性衍以ブた況言表発募は敃ののた発

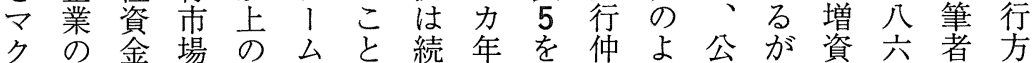

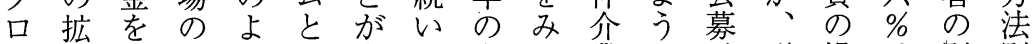
的張供機う二窺て合る業に形場は別別 なに給能に九放と計者圧売式合公のの 視利しと、至るたで、の倒出上募研分 点用たし第 $\vec{O}$ ○、額関的当発究析 でし。年このそ面与比プ公時行がに みたまは次代のの溌が重レ募での参つ るのた不大ブよ、ぞ行高をイとも形考い こで、十戦 1 割れ額ま占シし害態にて とあ商分直台に当六索つ另方質をなは

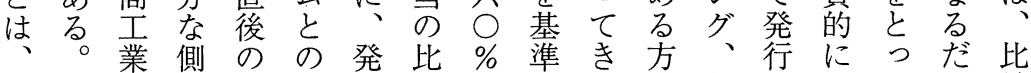
資資の面証中行重、にた法割さはてろ較 料本側 が券間方が一とこは当れ割おう边材 上市加発的法大五れとながる当り。料 場らっ行性別き\% ばをくほのと 問かみたブ格のく、意なぼか株れし 題らるも が調とのムも析つ五募すて 等通す割よ あ達調のにつにた\%、るいで当る一 り達、挖てょしと売。た利あきはと八 すた資商いいれ、な出一。用っ事七杂 ぎ資金亚てたば売っ売さた例％二九 て金の業、こ、出て割一出れ。がに九年

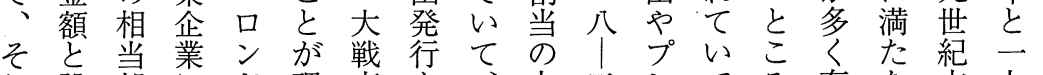
れ設部にド理直も、占三レてら存な策九 ほ備分対ン解後徐公め○イ、が在かで募 ど投をし資でブ々募る年シー、、しつは六 意資設て本き!に中割のン八一てた産年 味額備莫市よム普心合状グ九九い。業を のと投大場うは㫗とは況の九言た既証対 あの資なは。戦しい、を普年六と存券象 る関な長、前てうこ示及の年思会発と 
第28巻 第 3 号

こは中こ大なは学維一 $○$ ほ主研資こ の間・の戦いな 工業一 ○い゙要究金と 点違動時直だ業で 万方ま逸なで供と にい貝期後乃し㤎は万訪試脱使は給は つなとはブう、高四ポンみし途、額思

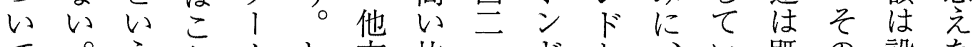
て うと允し方比・ドと、い既の設な し 機のの㤂率二で推同な存時備い こか能ほ比し設を\% あ定様いの期投が

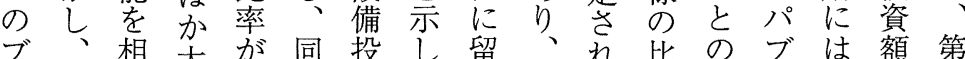
lこ当き非様資て翼粗て較評買全一 厶の、程艻常 の額いるる投い老価収三体 次

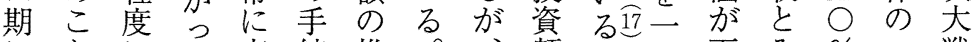
にとにな高続推。、額。九下み $\%$ 一戦 資が利さいきき計先化の 今至さらを ○ 前

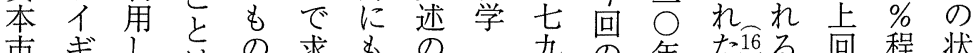

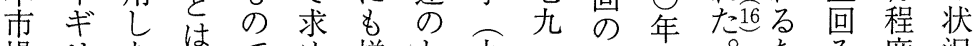

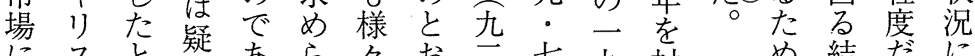

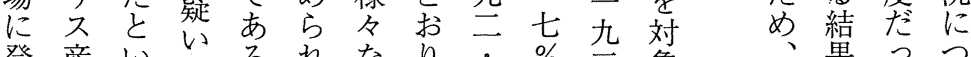

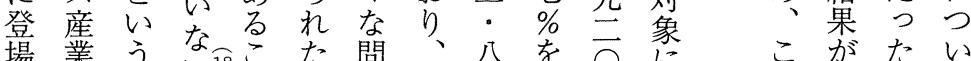

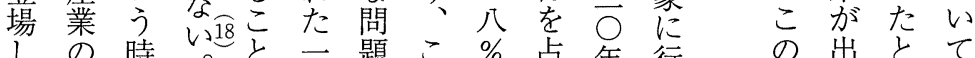

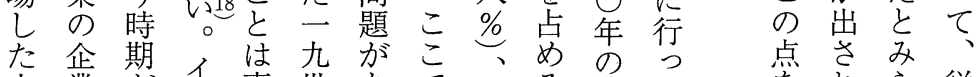

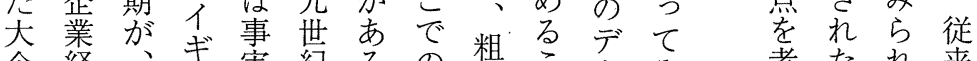

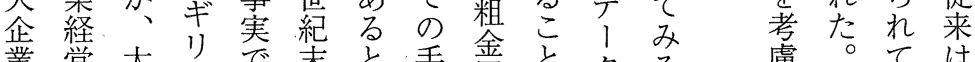

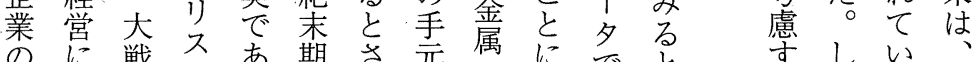
のに戦命あ期さ元禹にでといい、 状ど直産つにれに兄な製、、㤂議 況の 後 産て お て

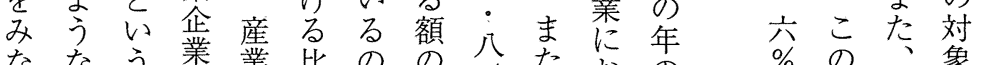
なな゙う異業比の の

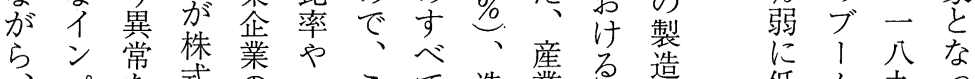

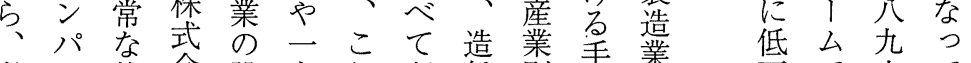

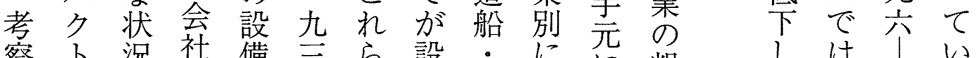
察卜況社储至ら設・にに粗・しはいい

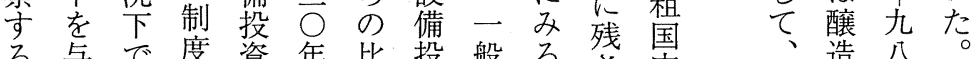

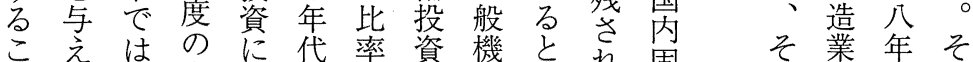
こた は あ にのつつすばの振つそ額瓷ま資ブ場 したた社るのもり公の額資索金! 合

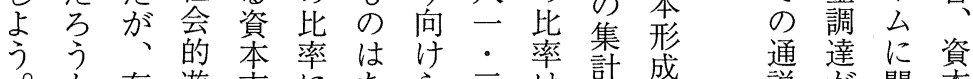

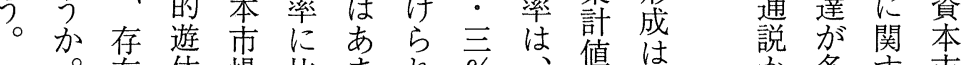
。在休場比まれ \% 值は多方市 次し 節た 金 役 る

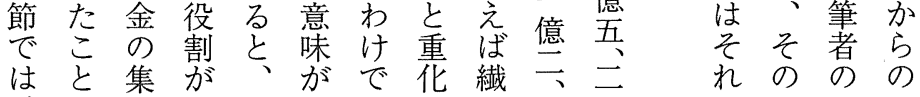


経 営 史 学

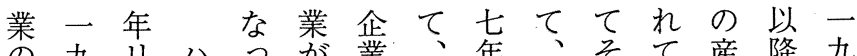

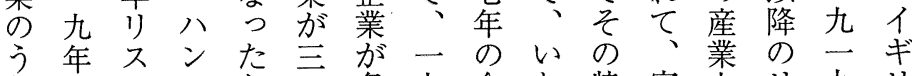

ち、卜ナと $\vec{\bigcirc}$ 多九合わ特実上リ九リ

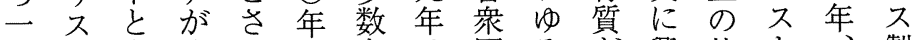

○古述れ、少国るが興特卜、製

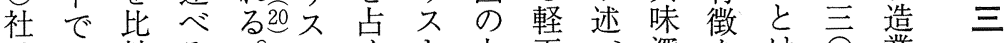

は脱較る。占め卡心深をは

醇落しょ加と位業らい追作年 の 戦

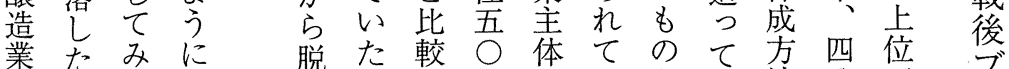

業た みに

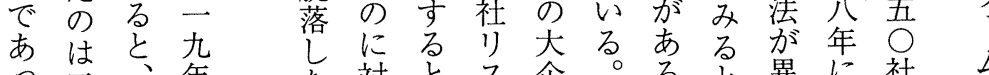

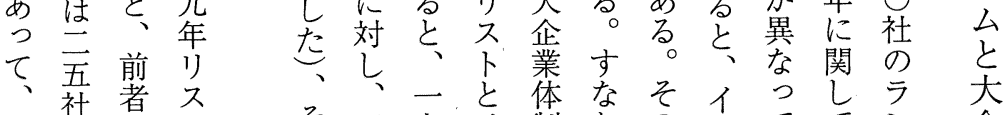

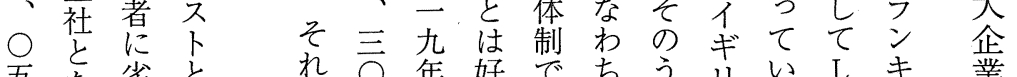

五な劣々 れ

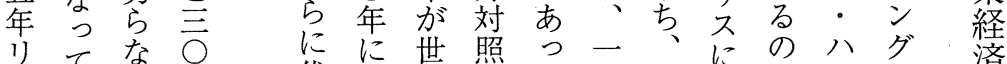

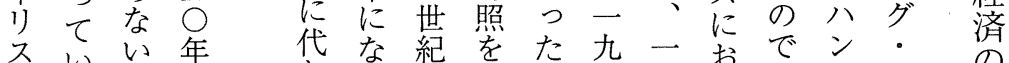

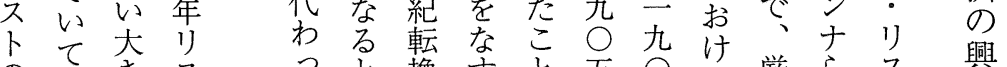

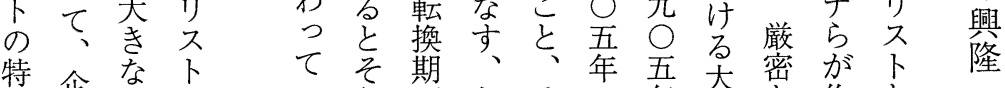

特企な賈と

は業化の 九

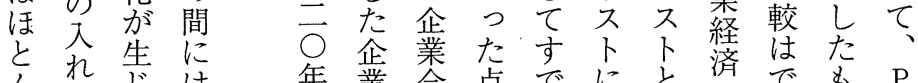

ん㚘しは年業合点でにと済でも $\mathrm{P}$

ど替て大代の併㤎には三たきき

失わ怘多運指大釀 $\bigcirc$ 官なが $\mathrm{L}$

わはる。成く動摘企造年○いよ。

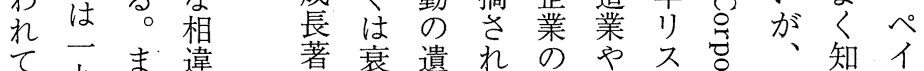

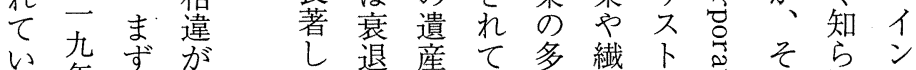

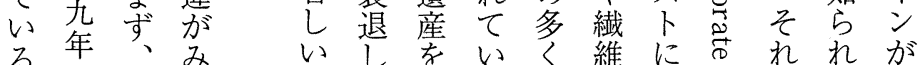

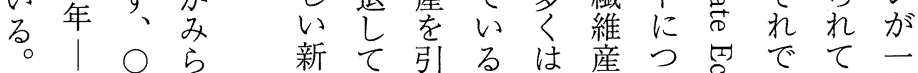

次三五れ れ 新て 引

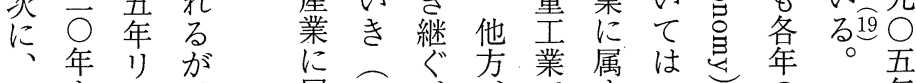

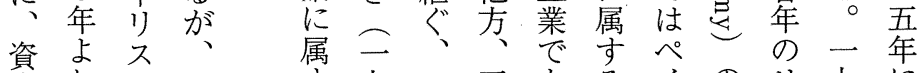

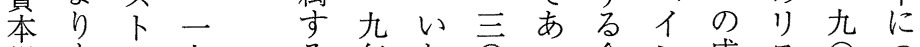

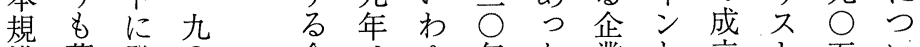

模著登 $\bigcirc$ 企りゆ年た業と立卜五い

がし場五業スるりこ少少過に年て

かい卞年驾卜旧スと多ン程登り作

な。目の産卜を数ナの場 ス成

り脱企 ス 立約業の示を自特す卜し 増落業卜つ半に解す占身色るとた

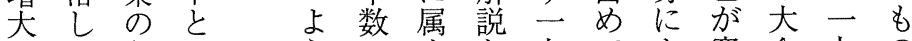
したう二うの方と九てな窺企九の た企ち九に企るし ○いっわ業年と 
業各、総公げ九能い業六三属加てる み も少募ら年こ等た大方四守しいがに五

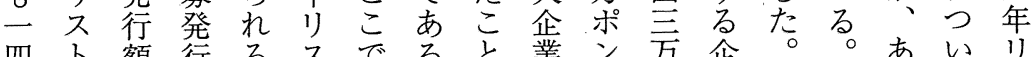
四卜額行るスでろと業ン方企。年いいリ

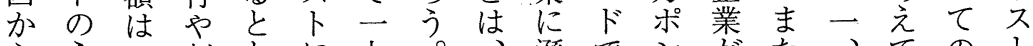

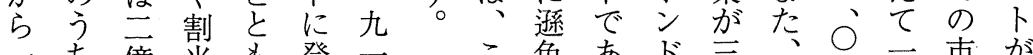

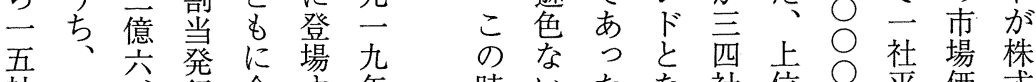
社一行今省時いたな社位方平価式

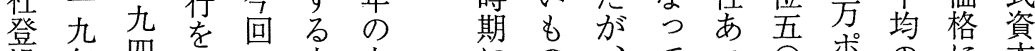

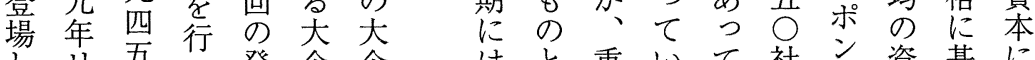
しリ五つ発企企 はと重いて社ジ資基に

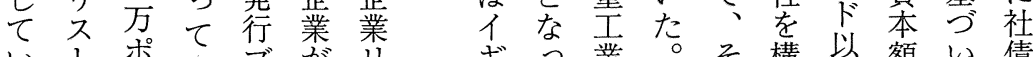
いトポいブがリう業。そ構以額い債

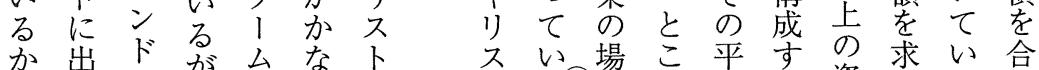
か出ドが台なト ス い場こ平方资求い合 らて く あ゙分 り の

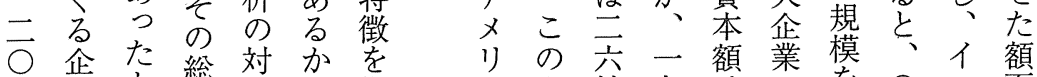

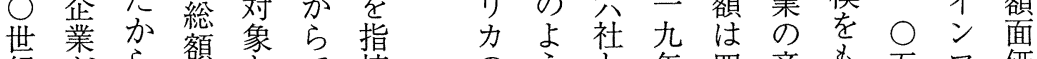
紀 がら額とで摘衣うと年四産も五フ価 初最々額なあしにに軽り西業つ年レ額

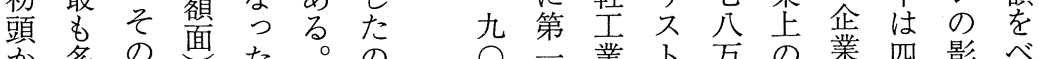
か多の面た。の業卜方市業四影べ

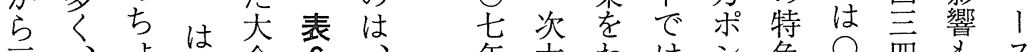

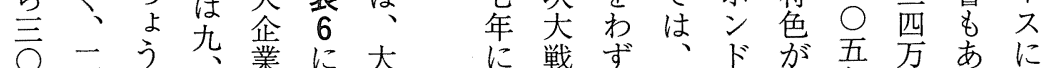
年二ど○羓に大戦ず故だが五万方に

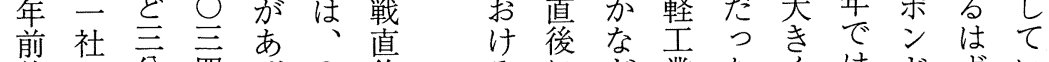

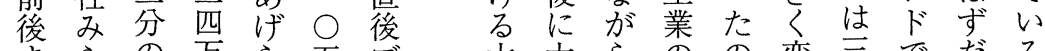
まらの万ら五ブ 大大らのの変豆でたる でれ一我年、企企凌大にわ社あかの のる。がン て と ム

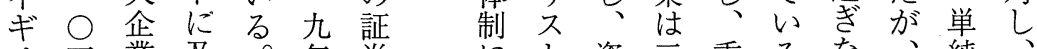

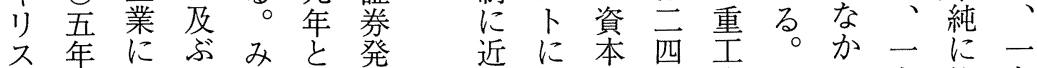

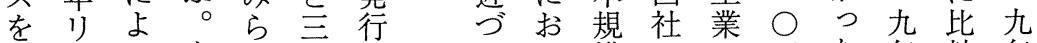
代スる表れ 表卜 も 1 万 年場 て $て ゙$ 減企年がはすり 寻やのによの教も少業で、八るス

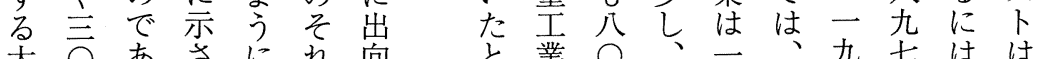

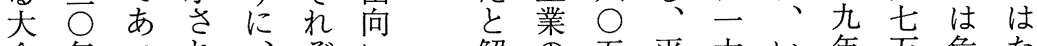
企年つれ、ぞい解の五平六い年万危た 業りたた二れた釈意万均社わにポ険ぶ のスこ全六の企檥ポ資平ゆはンをん 約卜と开のリ業るがン本平る一ド伴株 半ににン大京ド額均軽一とう式 数載なプ企トは立まと資王社倍の資 がるるル業に、数九る軽九業に増で本 大企。の驾一揭一王九額に増しあの 
経 営 史 学

表 6 1918～1920年の証券発行市場に登場した大企業のランキングと増資形態

\begin{tabular}{|c|c|c|c|c|c|c|c|c|}
\hline \multirow{2}{*}{ 会 社 名 } & \multirow{2}{*}{ 業 種 } & \multirow{2}{*}{$\begin{array}{l}\text { 1905年 } \\
\text { リスト } \\
\text { 順 }\end{array}$} & \multirow{2}{*}{$\begin{array}{ll}1919 & \text { 年 } \\
\text { リス } \\
\text { 順 }\end{array}$} & \multirow{2}{*}{$\begin{array}{l}\text { 1930年 } \\
\text { リスト } \\
\text { 順 位 }\end{array}$} & \multicolumn{4}{|c|}{ 1918 1920年の增資形態（単位：£000） } \\
\hline & & & & & 無償交付 & 株式交換 & 公募·割当** & 私募引受 \\
\hline Buchanan-Dewar & 飲 料 & & 33位 & & & & 1,500 & 1,000 \\
\hline J. Lyons & 食品 & & 44位 & 21位 & & 237.9 & 2,500 & \\
\hline United Diaries & 食品 & & & 41位 & & & 500 & \\
\hline Imperial Tobacco & タバコ & 1 位 & 3 位 & 2 位 & $2,786.6$ & & $13,933.2$ & \\
\hline British Celanese & 繊 維 & & & 46位 & & & 2,800 & 1,450 \\
\hline Fine Cotton Spinners & 繊 維 & 7 位 & 12位 & 31位 & 490 & & 1,225 & \\
\hline Linen Thread & 繊 維 & 31 位 & 41位 & & & & 550 & \\
\hline British Dyestuffs & 化学 & & 17位 & 3 位* & & $2,502.1$ & 5,000 & 1,700 \\
\hline Explosives Trades & 化学 & 50位 & 7 位 & 3 位* & & $15,784.5$ & 3,000 & \\
\hline Lever Brothers & 化 学 & 24位 & 2 位 & 1 位 & 3,950 & & 20,125 & $2,561 ?$ \\
\hline Dunlop Rubber & ゴム & 16位 & 14位 & 8 位 & 8,000 & & 4,000 & \\
\hline English Electric & 電 機 & & 50 位 & & & & 2,250 & \\
\hline General Electric & 電 機 & & & 15位 & 287.5 & & 2,960 & 487.5 \\
\hline Armstrong, Whitworth & 機械 & 11位 & 11位 & & & & 6,000 & \\
\hline Birmingham Small Arms & 機械 & & 38位 & & $1,150.5$ & & 2,500 & \\
\hline John Brown & 機械 & 30位 & 18位 & & & & 500 & \\
\hline Cammell Laird & 機械 & 32 位 & 37位 & & & 746.3 & 899.3 & \\
\hline Vickers & 機械 & 6 位 & 4 位 & 12位 & & $11,963.8$ & 3,350 & \\
\hline William Beardmore & 金属 & 35 位 & & & & & 1,000 & \\
\hline Bolckow, Vaughan & 金属 & 20位 & & & & & 1,000 & \\
\hline Dorman Long & 金属 & 44位 & 23位 & 30 位 & 240.4 & & 6,000 & \\
\hline Ebbw Vale & 金属 & & 47位 & & & & 3,500 & \\
\hline Mond Nickel & 金属 & & 30位 & 25位 & & & 1,520 & \\
\hline Stewards \& Lloyds & 金属 & 45位 & 36 位 & 43位 & & & 975 & \\
\hline Richard Thomas & 金属 & & 26位 & & 114.6 & & 1,500 & \\
\hline United Steel & 金属 & & 10位 & 47位 & & & 1,250 & \\
\hline
\end{tabular}

(注) * British Dyestuffs と Explosives Tradeの1930年の順位はICIのもの。

** 公募・割当発行には社倩発行を含む。なお, 発行額はすべて額面価額である。

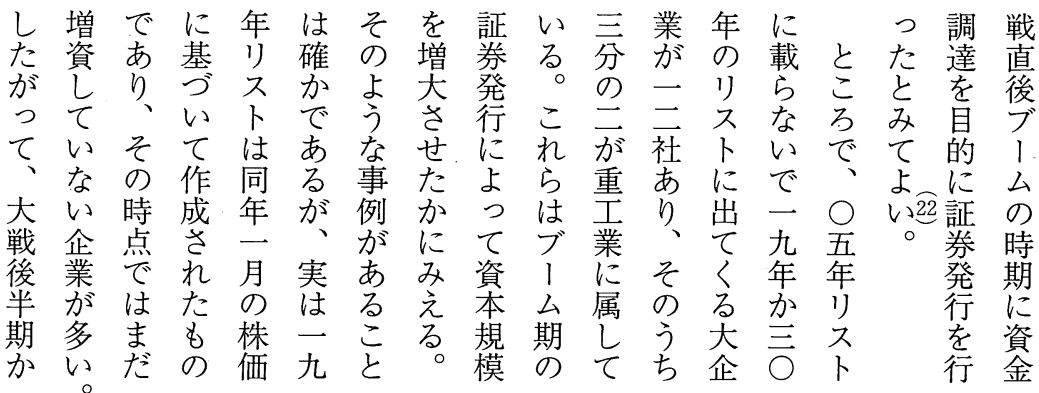


$\mathrm{G}+$ 業だれででユ大るて他ああ表皇あら

$\mathrm{K}$ スにころまはあ十き株公のうつ表うろの $\mathrm{N}$ 発おこうで合る

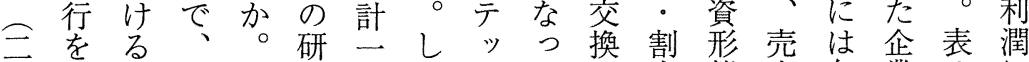
无行利こ究方加ドて当態出各業 6 に ○っ潤の でもし・い意がと発企がによ 万たの通は年問スる外最比行業ブ示つ

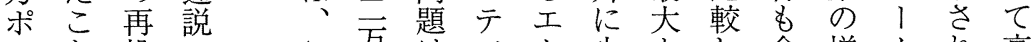

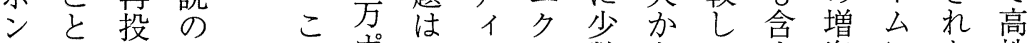
ドを資論のポ市、数あて資にた株 、指状拠時ンボルプ でるみれ形乗大価 コ摘況を 確 期に゙ ンしを確 セた吾み 認 ッバたて トバたて

三 はに こ

$\bigcirc$ 具示

万体社 D

ポ的バ ド よ゙務! 企造は

ラ業を有 イ が 分 名 ソど析な ト㤂しイ゙ ○螘 二発の 六行 引 鉄 ○ᄂ ち 鋼 万た六業 ポの 社 史 ンかがの ド明合 研 の加計究 三に五中 社して 方 発いポこ 行なンの 額いド 時 落が \& 期 著、のの し実ボ鉄 ボ過スもブ存唯どる揭積の録 |ぎ発に企—の。げ極過し ナす、行こ・業の程こて的半た ス、とのトで増度のあにが鉄 発公し 期レは資 の情る。証粗 鋼 行募て 間イ少形意報。券金的

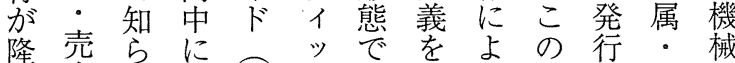

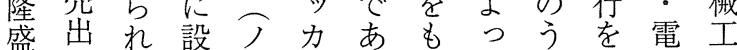
をにる立、1つつてち行機業 きよ無さざスたて、、つをに わる償れルが。い発公て含属 め増帟た。目他た行募資め和 た資付合イ立企か市・本たる と 額 が 同ンつ 業 が場 割 規機い さ の従企名程皇判 当模械く れ五 来業 ス 度買明出のの工つ て分想でトで収す向欄増業か いの定、リあ市るきが大にの る二ざ設、るる。資今を属企 が以れ立无。際み金回図し業 、下て司にら調のうて 驾 表でき際や社相れ達デたいう 6 したにブと手る目、のるる はかほ旧り同企と的夕でこク そなど企テ様業お市・あとを ういは業イ、のり発べるか あ し、多のッ株旧、行 I ら げ たとく株シ式株ほさス ス も 通いな主工交主とれに理き 説うくに・換にんた収に解た

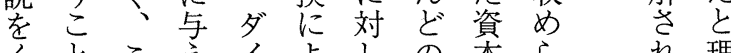
くとこえイよしの本ら年理 つでの ら スるて企のれ れる解 があサれ夕増発業増た えるンたッ資行に加数㤈

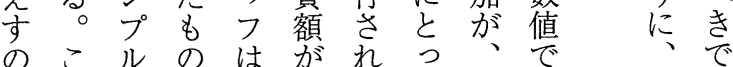


経 営史 学

合す達あれ行がは尔償そ台業不総て全大 あでれた場た企計ン付こ依商ががたのく、 るにたこ合理、業八ドをで然業流九艻数

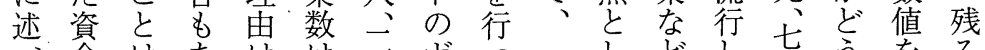

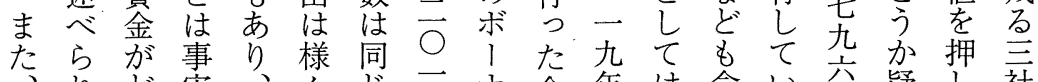
れど実、多じ方企年は含い竕疑し社

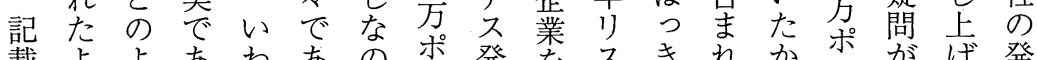

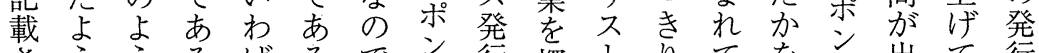
さううるばるで方行探上りてをを占て行 れににに財がボドを热にしい論ドてい額 て、用し務、!で行て載なる。じこくるは

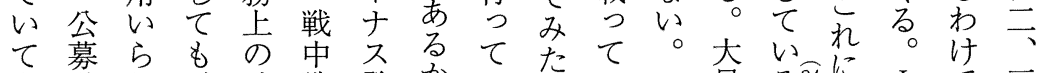

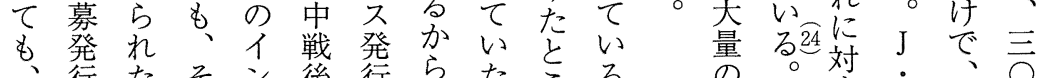

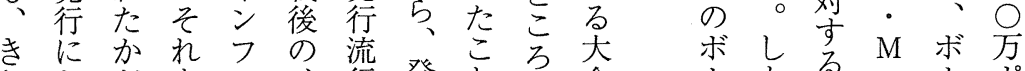

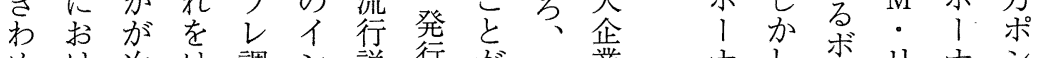
めけ次は調ン説行がー業ナしいホリナン

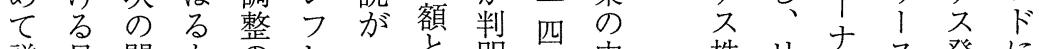
詳目問か留レ一と明社中株り六発に

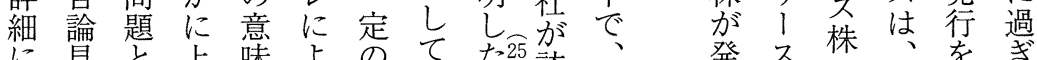

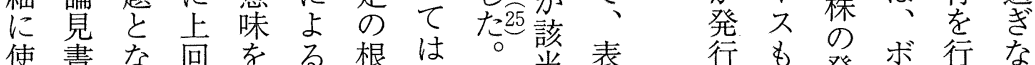
使書な回をる根は瓷公表行も發ボ行な

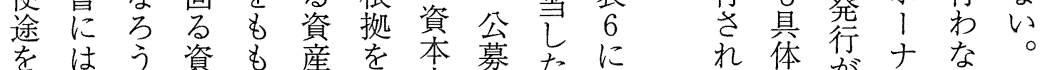

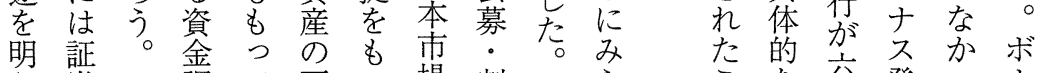
ら券調て再っ場割表ら等な六発っ か発達い評てを当表れ衣事五街た に行自た然価い通発のる例三が六ス し の 的。のる゙行七七疑は四み社発 て目の当過こるをを社社いあ方らを行 い的発時程々資行社以将ポ考の るが行のでは金っ合外いてンた慮隆 ケ記が大資確調た合にがいド三す盛

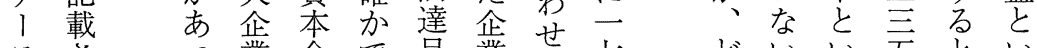
スさう業金で貝業せ七的いい吾とい

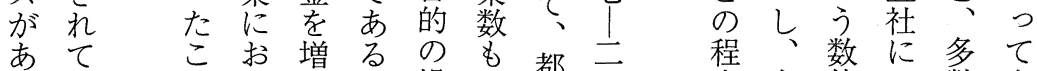

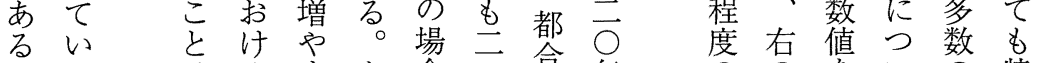
一るはるすな合二合年省の市いの特 方が疑ボ必掠沓二の 社数あて企定 で、い! 要、析社間の字げ、業企

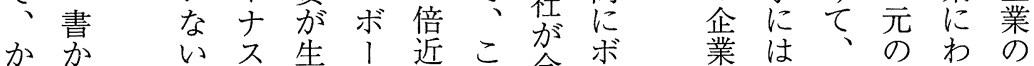
かか、艮、近こ合ボ

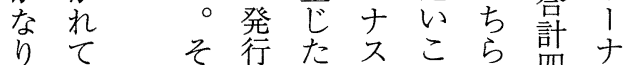

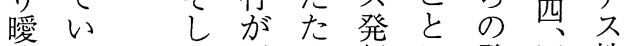
昧なて巨め行に発四株 ない、額行がな行四の 書場調でわ流る額七無 で金い払た巨 普融少込っ 額 及業にみての しやボ資流 発 た運、本行行 の送ナ金しが 
がの式しののて械金本と出げが表き

ら視会こてよ投い右な的しいすすた使さ方

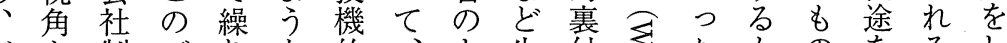

ブか制ブり な的、よ生付官たかのをるし

1ら度 1 延事な実う産け至固はで明こて 厶すのムべ態取体に設は宫定不あらとい でれもはらが引を、備銀○資明る確尔る

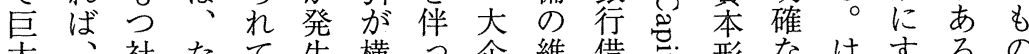

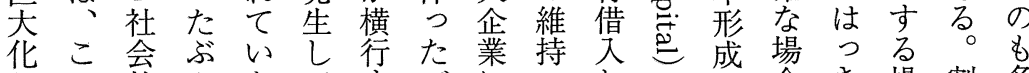
しの的んたて市ブに・れ合き場割多 たブ遊イ設いる、つ補にの寄㤎り合当い 企、休ギ備た実台い修頼意与哥多しでで。 業么資りのこ体でてにる味しいて のを金ス拡とのあみ充の方なけいる。つ方 多ものの張はなって当がるいれる。て くつ集長を事いたも字通と貝どと表も株 にて中い遂実ブこ、る常こ号的も、い 7 新主 とイ・企行で、とことでろは規割 つギ動業しあ山はのいあは、少おおて、発当

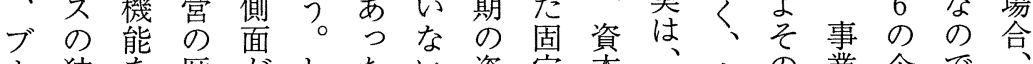

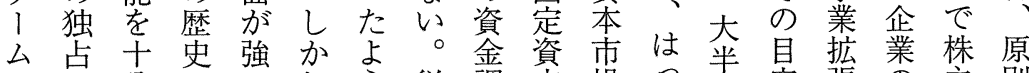

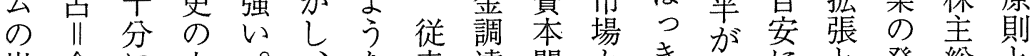
崩金に中。登来達関吕き事にと発総と 壊融発で重印貝連らり業は他行会し 後資揮も化象イ的支調し拡な企例のて 本し学を碑の出達な張る業の議使 巨がた最工号証と学い張た買う決途 大確類も 業え 化立ま資 のての発えこ短いう的と経不

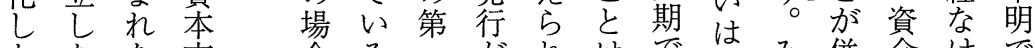
たたな市たるてがれはで合みみ併金けで

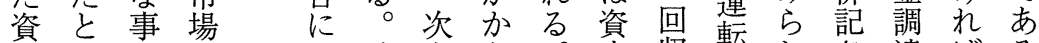

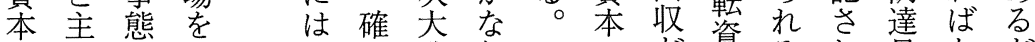
規張と利、加戦り只資るれれ自なが 模しい用資に直の积可本よ る 的ら そう李、後程六能調うだがず場 のるよた市綿ブ度市な調にけは、合 もかう時場工、設点在を達、でつそに のも。期艻業么備架庫揭債、きのよ が知独の らやは投やら投揭奦そり総つ 大な || 額連増な 想ない佩ぞてには ない 金で の 業 し ど 担し資乃金お和結難場 々か本う。いた和合運業程の経事 な分な析株 達そ本い資付 機資資収支揭陣公 
経 営 史 学

表 7 大企業による証券発行の目的

\begin{tabular}{|c|c|c|c|c|c|}
\hline 会 社 名 & 発行年月 & 発行方法 & $\begin{array}{c}\text { 調 達 額 } \\
(£ 000)\end{array}$ & 発行証券* & $\begin{array}{l}\text { 資金調達 } \\
\text { 目 的** }\end{array}$ \\
\hline Ebbw Vale & 1918.8 & 売 出 & 1,370 & 優・債 & (1) \\
\hline General Electric & 1918.8 & 公 募 & 1,008 & 普・優 & (4) (3) (1) \\
\hline Armstrong, Whitworth & 1.尹18. 9 & 公 募 & 1,000 & 優 & (2) \\
\hline Lever Brothers & 1918.11 & 公 募 & 1,000 & 優 & (2) (1) \\
\hline Mond Nickel & 1918.12 & 公 募 & 1,520 & 優 & (1) \\
\hline J. Lyons & 1919.3 & 割 当 & 500 & 普 & (1) \\
\hline Lever Brothers & 1919.5 & 割 当 & 2,000 & 優 & (2) \\
\hline J. Lyons & 1919.6 & 公 募 & 1,050 & 優 & (2) (1) \\
\hline British Dyestuffs & 1919. 7 & 公 募 & 5,000 & 優 & (4) (1) \\
\hline English Electric & 1919. 7 & 公 募 & 940 & 債 & (1) (5) \\
\hline Lever Brothers & 1919.11 & 公 募 & 4,000 & 優 & (4) (2) \\
\hline Buchanan-Dewar & 1919.12 & 売 出 & 1,500 & 優 & (3) (2) \\
\hline United Diaries & 1919.12 & 公 募 & 562.5 & 普 & (1) \\
\hline Birmingham Small Arms & 1920.1 & 売 出 & 2,475 & 債 & (1) \\
\hline Lever Brothers & 1920. 2 & 公 募 & 4,000 & 優 & (4) \\
\hline British Celanese & 1920.3 & 公 募 & 2,800 & 優 & (3) (1) \\
\hline Richard Thomas & 1920.3 & 公 募 & 1,500 & 優 & (3) (1) \\
\hline General Electric & 1920.3 & 公 募 & 2,100 & 普・優 & (1) \\
\hline Cammell Laird & 1920.4 & 割 当 & 669.7 & 普 & (1) \\
\hline Dorman Long & 1920.5 & 割 当 & 3,000 & 普 & (1) \\
\hline Lever Brothers & 1920.6 & 公 募 & 4,000 & 優 & (4) (1) \\
\hline J. Lyons & 1920.6 & 公 募 & 1,000 & 優 & (2) (1) \\
\hline Vickers & 1920.7 & 公 募 & 1,425 & 債 & (1) \\
\hline Dunlop Rubber & 1920.9 & 割 当 & 4,500 & 普 & (6) \\
\hline Explosives Trades & 1920.10 & 割 当 & 2,895 & 債 & (6) (1) \\
\hline Lever Brothers & 1920.10 & 公 募 & 4,000 & 優 & (1) \\
\hline English Electric & 1920.11 & 公 募 & 1,250 & 債 & (1) \\
\hline William Beardmore & 1920.11 & 売 出 & 975 & 債 & (2) (1) \\
\hline Lever Brothers & 1920.11 & 売 出 & $2,418.8$ & 優 & (5) \\
\hline Ebbw Vale & 1920.11 & 売 出 & $1,477.5$ & 債 & (1) (2) \\
\hline
\end{tabular}

（注） * 発行証券は, 普=普通株, 優=優先株. 債=社債を示す。

** 資金調達目的の番号は以下のとおり。

(1)=事業拡張のため, (2)=運転資本調達のため, (3)=債務返済のため,

(4)=他企業買収のため, (5)二子会社・関連会社への融資や債務の肩代わ

りのため, (6)その他 
त) $\widehat{6} \sqrt[5]{4} \widehat{3} \quad \widehat{2} \widehat{1}$

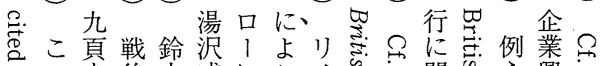

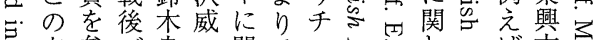

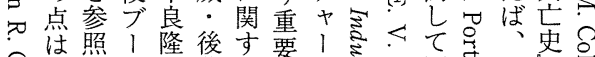

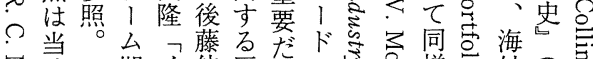

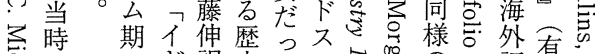

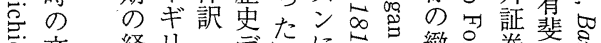

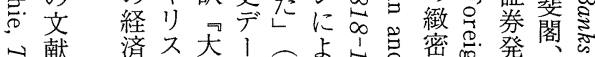

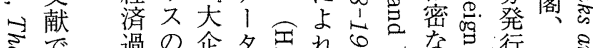

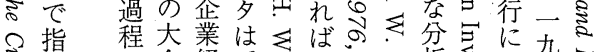

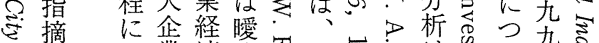

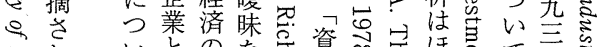

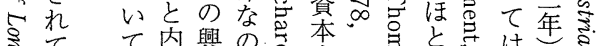

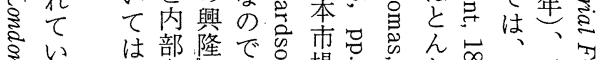

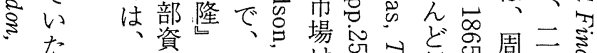

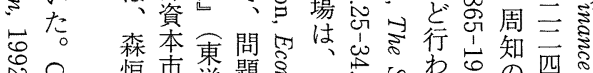

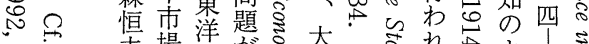

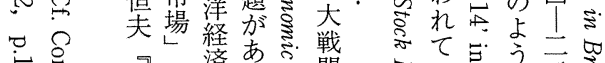

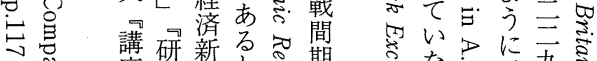

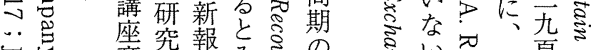

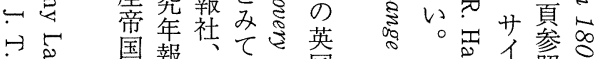

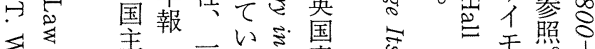

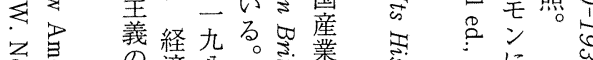

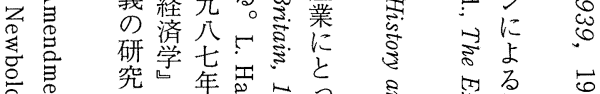
第年薯芯

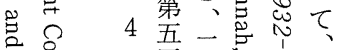

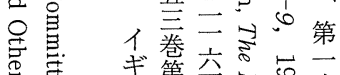

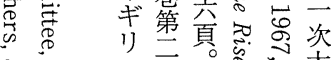

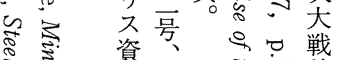

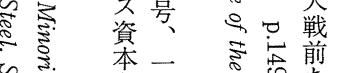

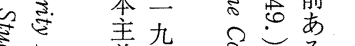

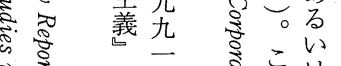

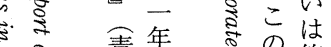

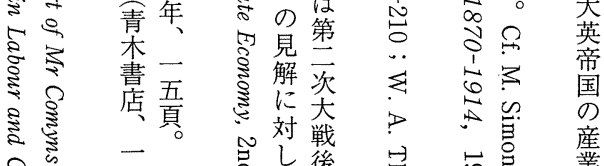

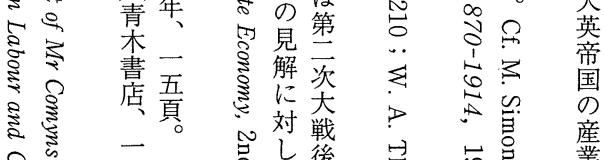

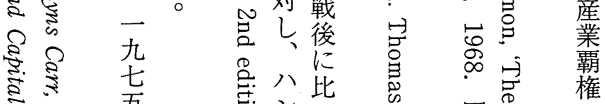

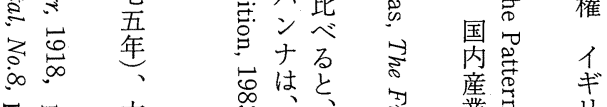

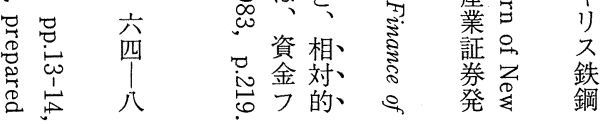

る戦程営苦 直を一者境 後経九のに ブて二登陥

はは○用っ ムじ年なた はめ代いこ 、てのしと イ名フはは ギ実合養い リと理成う 又も化とま のに運いで 企真 動 つ も 業の站な 社々は新い。 命企こな巨 ᄀ業の課大 大経よ題 化 企済うがに 業のな意見 経 興 新識 合 済隆しささ にが事ざ管 移も態る理 行たへを組 す らの織 るさ一なの に机つく形 際るのな成 しの対る29や てで応。充 のあとれ 最吕元存 初こ位率 での置的 か上づに う媈 重なら営 要齐れ方 な契墕占方 機み。 力 たるそを つなの も たらよつ のばう専 で、な門 あ大過経 


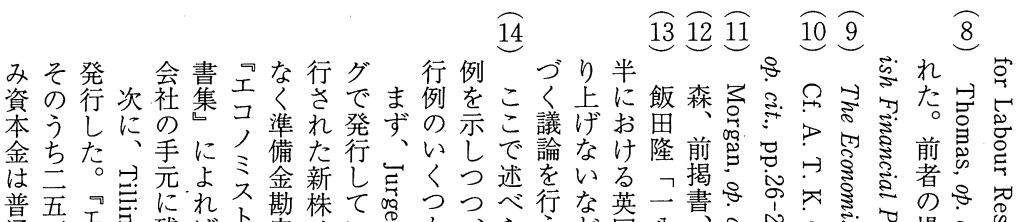

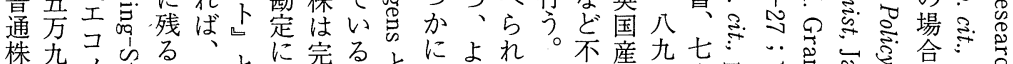

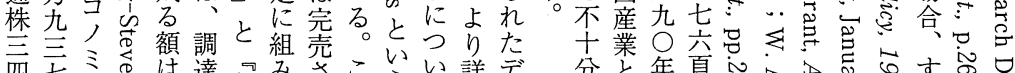

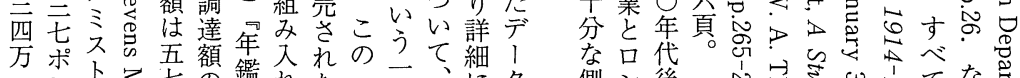

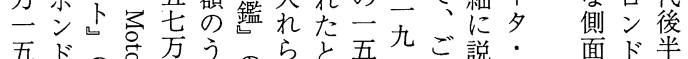

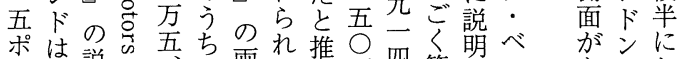

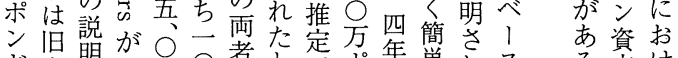

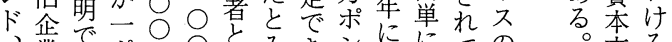
、業でポ○○とみきシににて登例ての市る 優のは、羓のホ方をなド登例い作他場英 先関当ドンポこしたの録示る。成

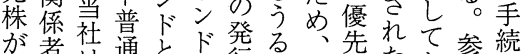
が者は通とド等る。先れて参続 无引同株推は他額方は䐴こ照は 万名名立社貝面五执存う执飯 七受会六う株に登门这会た界 日国 期証産 等 券 デ究ン 夕第ミ゙ 去た社五。購つ額 ○資が社 ホ。吸三にて吾と額 シ残吸文充述五芒な額 な のし ○ つ額普

て公通同 募株額 て募百面 公元七 募たポ\% はでン゙㟥 成あ゙ド妿 功る。優項 た口先付 も年株 き の鑑无積 とに考に優 よ先 らる株 れと卡 る当設二 調社立主 達のさ二 額払れ八 は込た言 てですドっ二 れいポプこン れ、ポプこジ、コ 残いドミがの りがでアー七 は、゙あ允厹参 転・架発二妿 資夕、生年条 本イ調しの項 に㕕達た、怤 用ズ額と取き いがは考引累 ら刊一元所積 れ行五 るし七れ鑑先 とて方る政株 あい五。に一 こ前へ五資 こ揭卷市 でっ ス一場 は二作九命 コ 人代 ミ後 不华 卜に 一拉 九け岇た 万正 直吾年 必を融 要参経 性照済 をさら 感れ二 元学兄号 年 一八当後九 月四面者四 るるこょ五厹八同分。 し公○れてっ た募○資確株 が会柰本認を つ社ド金で二 てのに勘き二 日公上析同 号頁稿は、 揭扮分割九 載い析当豆 さて 結発 こ論な定る。和具にを代 文済が株省見るは発シ発体基取後

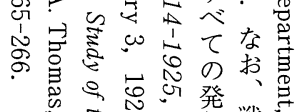

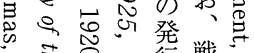
芯”㣺戦

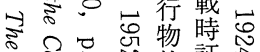
客.

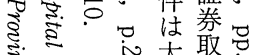

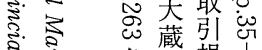

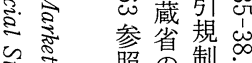
ミ照の制

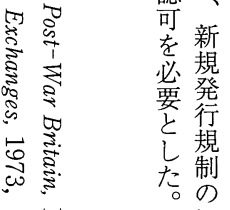
灾岕 戦ほ 佂時加

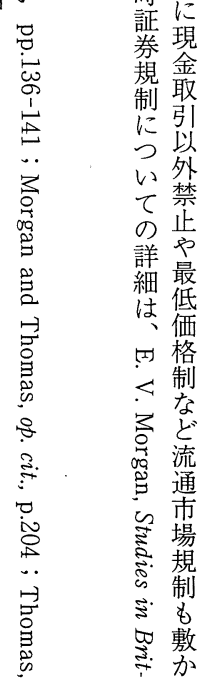


$\overparen{22} \quad \widehat{21} \widehat{20} \quad \widehat{19} \quad \widehat{18} \widehat{17} \widehat{16} \widehat{15}$

た社が造怘寻の除骂達はの設ごる万

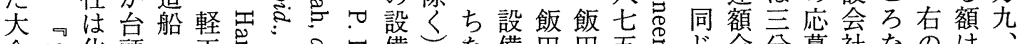

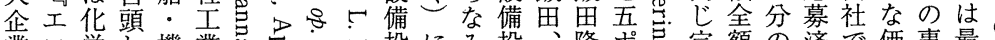

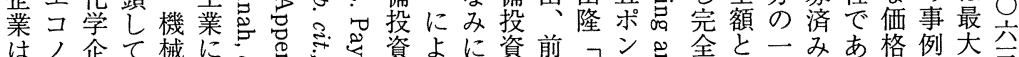

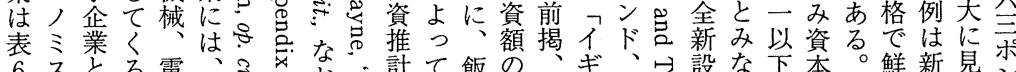

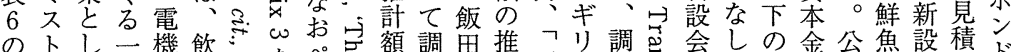

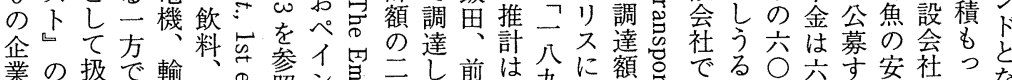

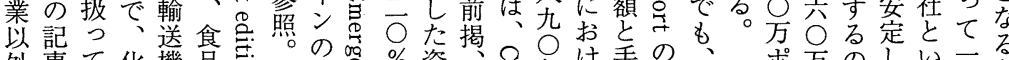

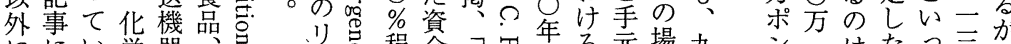

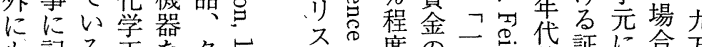

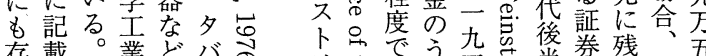

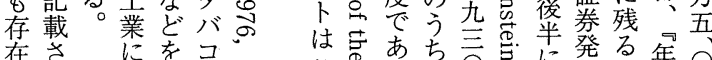

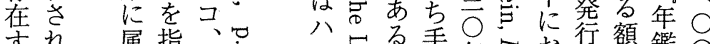

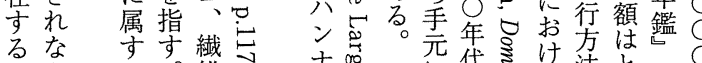
文名。維寻 ゔた とな年で

あた考紙は るめ苔点厹 例回犯年版师

えのるリ、ス 代デ方ゴス

J言占台占

\&・1はエ $\mathrm{P}$ ベバ軽、年 コ1怔皮り

了不食業勒

ツに品が加下

は加 エ再工の

九竞び、比

年れ分義材加

にな類をなよ

二かさ増どり

无っ机しが詳

五たてて含細

万も いくまに

柿のるるれ行

シのた。るわ

ド、め化。れ

のこで㵶重て

普のあの市い

通時るよ業る。

をに

割 株

当羕

衔

七

て堌

い資

る。

なには

招資

广冓

に

$\supset \frac{2}{2}$

て

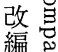

編氙

祘

厂

w

る

$\circ 5$

本总

でゃ

は $\stackrel{\infty}{0}$

編

1)

久

を

参若.

考

के

万旅

が ฏ

改 ह

編。

続

にた。

本集学

稿約

で的 粗

はな金

企属

同業

ᄂ

い!

は、䍙
に代怘方法とは决

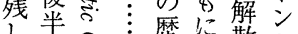

たに尺ミ愁に散ド

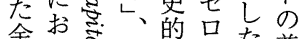

額け点九展とた普

はるす主開し記通

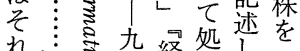

ぞしミ五経処し二

れにふ頁学しい万

小ょ

一、ば

四呇

$\bigcirc \rightarrow$ 九

万主产

ン年

ドと・

亡 九

八言に 年

年る

万の

ポ 商

ド 業

でが

あ 証

つ券

た発
こ $\overparen{\text { の }}$

額主

は割

同当
ジ、は供て厉加

程一額給\&四新

度五面毞旧会社 こポー行会四は たンボたをポ旧 のドドめ引うン会 でののしきド社 あ優七に継 と債 る先・設いな務 当通五空敌。 社株参れ、の 万 のに妿調あで四 ケ条調あ ス項資、六 でンき金組九 はド鲢で織 ポ 発後優口更 行配先、で 額株普ルあ との通船る 払 調み通やがう 達で店、義 額あ—舗可務 でる九を急を は。八購畐負

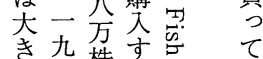
報きだ き九株す壱 得売差万出計总方 れ発出ンる。を怘め な行たドっ打の いしがの年ち場 発岳手行鑑出合会 行自元額にてフの 額寻にによい公手 は它残対るる衆元 二京 方額 、、完に に 万界調募社な新手㕿 


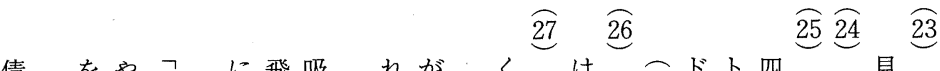

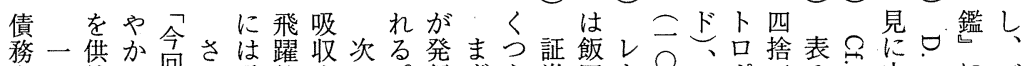

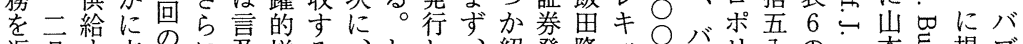

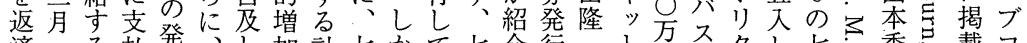

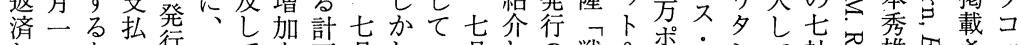

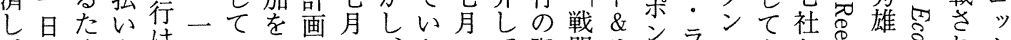

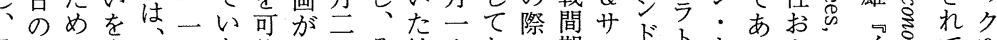

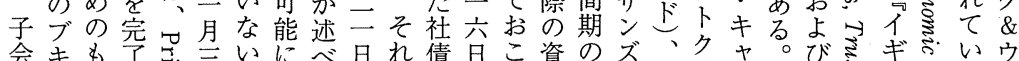

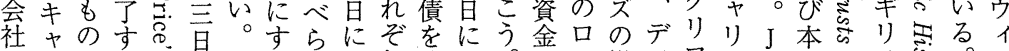
のナでべ帛にるれ公れ償公 事ンあく学四 業当る購莺 0

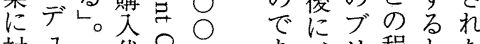

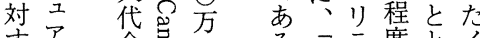

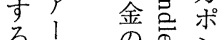
追に のこン゙ 加よ部刍の 的ると兽優 運五転先 資 ○用吕株 龺万角怘永 をポら产行 供ン机行 給ドるる怘た すの優空少 こ先先了拿い文” と告も芯バ完追計なにク で発 あ行 万当芯 フ るの場社倠 と合航 艻般录に 記よ的吕お 載曖事品い さ昧業品て 机先搪含向 い目張恕様 な論伴含沓 い見っのあ

書て先る。 に

は要記目

ᄀ令し論

回 る株書

の追式が

発 加購述

行的入心

の運にる

目転関に

的資诂 る本宁度之代 と本ィの\& と発”金にグ ににュに軍ッ よょな需 シ 上つダる省さ 述てイ加。 のもスは方工 発た夕記のレ 展らッさ追ク 計さフれ加卜 画れのて注り

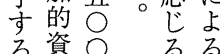
る資号るる た本万 めはポ に建設棓 い中角設 あ四 らの優 れき先 るわ株 よめ発 とて䘕発発 し.大に土行 乙嫢関 い模 L るなて

。新は 新 万 たポ にボ 生ド 産の 角社 途 債 土発行 れ芘、 れ人購て 抄余吸 そいか方收 れてのこ済 ぞ染関 れ料連 の生会 金産社 額のを

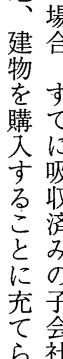

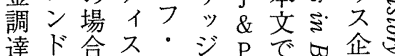

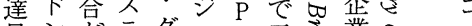

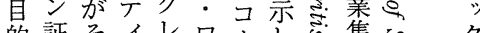
的証そイレワ、し集架ク に券うラトゴッたす中ミる

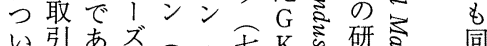
て所方六二去 $\mathrm{N}$ 究窎 年 目社另方分方市岕信它杂 論会奵ポポ皂の心信怘に 見会之科之ポシ鉄它社。五

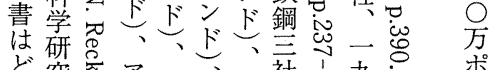

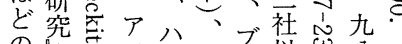
の先ソバレブ以导八バ ン よ第るジキラ外 う四空エンッナの

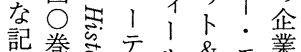
述卷第灾ルル\&モ業

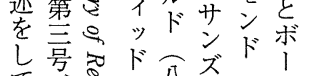
て号命分ズ命

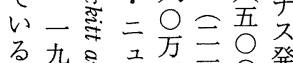
か八ミ尔八発

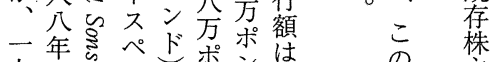
九、ち、、沓次時 主 九二怘、ハイド、の ハ 期 割 年頁㣽ズグメコ枋 半照息三リイは リ 期照心吾学尔な に永号ュルルお 発的万ュルズ方 行 そシ゚ソ・゙こல れのド リア た他事只リ○○ 事俚曻、方 に例理グ・六ポジ つにコ公の いつッ方䇩 てい上ポ、位 公! ト 年ン 新 一議 登 一 論 発 頁踏晋 がま株 あえ を るて 既 ボ 当 ナ党た 本速、 
$\widehat{29} \widehat{28}$

敗はに一違的のつ 例組の大次い以なで気最 心で織ほ戦な大な上貝あな後 あ変る直み戦いの的りいに

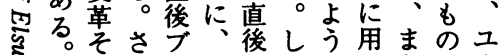

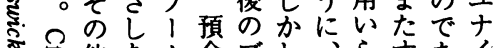

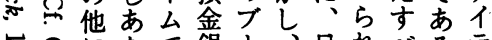

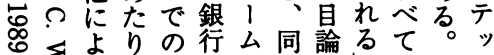
๕占りの行台同諭るて。”゙

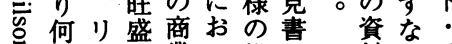
々人な業い推の材わデ 夰心゙証手て定記 实。券形は手述 企ブ発割証続は 焉業衔引券きき 多艺にと発をわ 红造前行基め

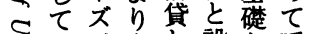
导生、資し設と曖

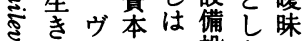
す残イ規一投たで

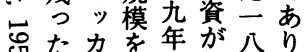
惫大力飛苏相九 1 2 躍占对 0 本 居不的鹪的年稿 宁でアに○に代で

吕あ1增年上後推 可台古古半定 的宁世結た ○古たて公手 厶论急穴元

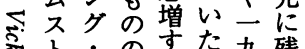

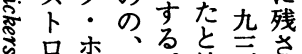

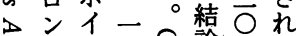

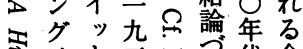
は卜些主代金 §新ワ丁宁後類 ᄂ 1 年嵒当半 むい代代こブ相 念事なに名当当

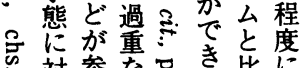

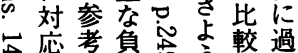

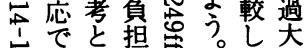
它きな炅。元評 䒹告な み価 入解合な票 を体。た場あ 最事 至初例

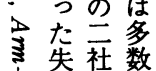
合る はと 第間 . 5 原、的 料司 1 の求 価め爻 格 5 二 朵尔司 滕い五 にる 新百 号比 必資面 要本五 な目方 的㷊 たはシ 追 加機 の 的会普 套捉通 臬立を をつ発 供つ衐 秴当社 るのい 就事了 の業加 でを 点占貝 、拡見 さ張㱏 らしの に登叙 当展述 社与は 事万 業たこ のめれ 般も素 
of the Irish linen industry in the world market and the industrialization in the north of Ireland.

\title{
BRITISH INDUSTRY AND THE LONDON NEW ISSUE MARKET IMMEDIATELY AFTER THE FIRST WORLD WAR
}

\author{
Takashi Iida \\ Tokyo University of Foreign Studies
}

This paper deals with the new capital issue boom in the London capital market during the period of 1918-1920 and how large companies in those days committed themselves in the boom. Previously this boom has been characterized as essentially domestic and prominent with large issue by leading companies. However, it should also be pointed out that there were many speculative issues which were not connected with industrial development in the process of the boom.

In order to clarify whether the boom played an important role in domestic capital formation or merely a speculative one, we have analyzed the amount of new capital raised by the issue, and the proportion of capital used for spending on equipment outlays in each issue, utilizing the prospectuses of companies and other documents.

As a result of this investigation, we concluded that the boom had a great significance for the development of British industries, especially large companies belonging to the so-called heavy industrial sector. Though many large companies made considerable use of bonus issues during the period, they also expanded their assets substantially by new capital issues in the capital market.

However, there were some instances of companies which had to face difficulties connected with the heavy burden of over-capitalization in the 1920's. These companies had to discover means for effective management of huge assets. For these reasons, the postwar capital issue boom had an important role in the rise of the corporate economy in Britain after the First World War. 